УДК 551.332.26:550.4: $551.79(571.6)$

\title{
ГЕОХИМИЧЕСКИЕ ИССЛЕДОВАНИЯ ОЗЕРНОГО СЕДИМЕНТОГЕНЕЗА НА ДАЛЬНЕМ ВОСТОКЕ
}

\author{
П. С. Минюк, В. Я. Борходоев, С. С. Бурнатный \\ ФГБУН Северо-Восточный комплексный научно-исследовательский институт \\ им. Н. А. Шило ДВО РАН, г. Магадан \\ E-mail:minyuk@neisri.ru
}

\begin{abstract}
Исследованы озера Курильских островов (Малое, Токатан, Пернатое), Магаданской области (Гранд, Чистое, Большое), Якутии (Щучье), Чукотки (Эльгыгытгын). Геохимические параметры использованы для определения генезиса осадков, характеристики среды и условий седиментации, постседиментационных изменений. Биогенное накопление кремнезема характерно для оз. Малое, Пернатое, Гранд с максимальной интенсивностью во второй половине голоцена. В оз. Чистое, Щучье, Большое доминирует в основном детритовый кремнезем. Потери при прокаливании использованы для оценки относительного количества органического материала, содержания которого максимальны в голоценовых осадках оз. Малое, Гранд и Большое. При доминирующей роли биогенной седиментации низкие значения потерь при прокаливании указывают на поступление кластического материала в бассейн. Параметр $\mathrm{Al}_{2} \mathrm{O}_{3}$ I $\left(\mathrm{Na}_{2} \mathrm{O}+\mathrm{CaO}\right)$ является индикатором размерности зерен с большими значениями для тонкозернистых осадков. Отношение $\mathrm{Fe}_{2} \mathrm{O}_{3} / \mathrm{TiO}_{2}$ в сравнении с $\mathrm{Fe}_{2} \mathrm{O}_{3}$ служит показателем детритового и хемогенного (биогенное) происхождения железа. Марганец в осадках озер Курильского архипелага связан с детритовыми минералами, в то время как для озер континентальной части Северо-Востока - с аутигенными. Тренд выветривания коренных пород, грубозернистых и тонкозернистых озерных осадков указывает на локальные источники сноса.
\end{abstract}

Ключевые слова: озерный седиментогенез, геохимия, плейстоцен, голоцен, Дальний Восток.

DOI: $10.34078 / 1814-0998-2020-1-57-73$

\section{ВВЕДЕНИЕ}

Геохимические данные несут важную информацию об условиях седиментогенеза в озерных бассейнах (Bovle, 2002). На химические характеристики озерных осадков влияют состав горных пород источников сноса, степень их химического и физического выветривания, способы транспортировки материала в бассейн, постседиментационные преобразования (Fralick, Kronberg, 1997; Юдович, Кетрис, 2011). Важное значение имеют физические параметры озер, площади водосбора и их залесенность, проточность озер, географическое и гипсометрическое положение, генезис и возраст.

Геохимические характеристики озерных осадков используются как индикаторы палеоцунами (Chagué-Goff et al., 2017; Moreira et al., 2017; Avşar, 2019), сейсмичности (Archer et al., 2019), турбидитов и склоновых отложений (Sauerbrey et al., 2013; Bellwald et al., 2019), солоноводных и 2020

(C) Минюк П. С., Борходоев В. Я., Бурнатный С. С., пресноводных фаций (Wei, Algeo, 2019; Schmidt et al., 2019), уровней океана (Frugone-Álvarez et al., 2017), вулканической активности (Chen et al., 2019), биопродуктивности (Tanaka et al., 2007; Brown, 2011; Melles et al., 2012; Minyuk et al., 2014; Adamson et al., 2019), а также различных климатических (Minyuk et al., 2014; Страховенко и др., 2015; Минюк, Борходоев, 2016; Bulkan et al., 2018; Sun et al., 2019; Speranza et al., 2019; Rapuc et al., 2019) и экологических (Даувальтер, Кашулин, 2014) показателей.

Планомерные геохимические исследования озерных осадков на Северо-Востоке России начали проводить с начала 2000-х гг. по пилотным колонкам оз. Эльгыгытгын (Минюк и др., 2003, 2007,2011 а) и кернам глубоководного бурения озера (Minyuk et al., 2014) в рамках международных проектов. Впоследствии были получены детальные характеристики по элементному составу осадков из озер Магаданской области, Якутии, Курильских островов.

В данной работе анализируются некоторые геохимические индикаторы озерного седиментогенеза, их применение в различных озерах и воз- 
можности использования для определения генезиса осадков, характеристики среды и условий седиментации, постседиментационных изменений.

\section{ОБЪЕКТ ИССЛЕДОВАНИЙ}

Объектами исследований являлись озера Востока России, имеющие различные генезис, параметры, возраст, физико-географическое и геологическое положение (рис. 1).

Исследовано кратерное оз. Эльгыгытгын (Чукотка), группа прибрежно-морских озер Курильских островов: оз. Пернатое (о. Парамушир); оз. Малое (о. Итуруп); оз. Токатан (о. Уруп), а также ряд ледниковых, термокарстовых, тектонических озер Магаданской области и Якутии, расположенных в межгорных впадинах, долинах крупных рек, на водоразделах - Гранд, Чистое, Большое, Щучье (см. таблицу).

Puc. 1. Местоположение исследованных озер: 1 Малое, 2 - Токатан: 3 - Пернатое; 4 - Чистое; 5 Гранд; 6 - Щучье; 7 - Большое; 8 - Эльгыгытгын

Fig. 1. Location of the studied lakes: 1 - Maloye, 2 - Tokatan; 3 - Pernatoye; 4 - Chistoye; 5 - Grand; 6 Shchuchye; 7 - Bol'shoye; 8 - El'gygytgyn

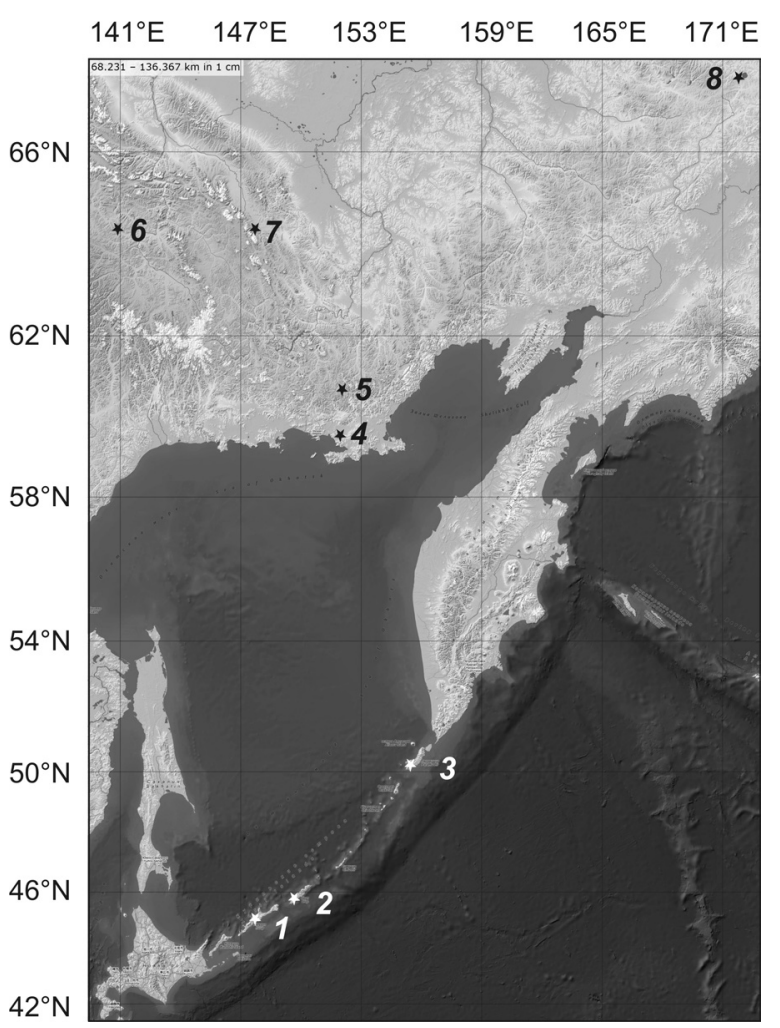

Объекты исследований озерных отложений

Lake sediment research objects

\begin{tabular}{|c|c|c|c|c|c|c|c|}
\hline Озеро & $\begin{array}{c}\text { Месторасполо- } \\
\text { жение }\end{array}$ & Координаты & $\begin{array}{c}\text { Макси- } \\
\text { мальная } \\
\text { глубина, } \\
\text { м }\end{array}$ & $\begin{array}{c}\text { Скважина, } \\
\text { мощность } \\
\text { осадков }\end{array}$ & Возраст & $\begin{array}{c}\text { Кол-во } \\
\text { образцов }\end{array}$ & Источник \\
\hline $\begin{array}{l}\text { Эльгы- } \\
\text { гытгын }\end{array}$ & Чукотка & $\begin{array}{l}67^{\circ} 30^{\prime} \mathrm{N} \\
172^{\circ} 05^{\prime} \mathrm{E} \\
\end{array}$ & 174 & $\begin{array}{c}5011-1 \\
315 \mathrm{M}\end{array}$ & \begin{tabular}{|c|}
$\begin{array}{c}\text { Поздний плио- } \\
\text { цен }\end{array}$ \\
\end{tabular} & $>5000$ & $\begin{array}{l}\text { Melles et al., 2012; } \\
\text { Minyuk et al., } 2014\end{array}$ \\
\hline Токатан & о. Уруп & $\begin{array}{l}45^{\circ} 51.3^{\prime} \mathrm{N} \\
149^{\circ} 47.9^{\prime} \mathrm{E}\end{array}$ & 13 & $\begin{array}{l}\text { Скв. 3, } \\
708 \text { см }\end{array}$ & Голоцен & 63 & Эта работа \\
\hline Малое & о. Итуруп & $\begin{array}{l}45^{\circ} 05.2^{\prime} \mathrm{N} \\
147^{\circ} 42.0^{\prime} \mathrm{E}\end{array}$ & 3 & $\begin{array}{l}\text { Скв. } 1 \text {, } \\
1540 \text { см }\end{array}$ & То же & 322 & Lozhkin et al., 2017 \\
\hline Пернатое & о. Парамушир & $\begin{array}{c}50^{\circ} 2.4^{\prime} \mathrm{N} \\
155^{\circ} 23.7^{\prime} \mathrm{E} \\
\end{array}$ & 1.8 & $\begin{array}{l}\text { Скв. } 3, \\
696 \text { см }\end{array}$ & $-\gg\rangle-$ & 67 & $\begin{array}{l}\text { Минюк и др., 2013; } \\
\text { Anderson et al., } 2015\end{array}$ \\
\hline Гранд & $\begin{array}{c}\text { Магаданская } \\
\text { область }\end{array}$ & $\begin{array}{l}60^{\circ} 44^{\prime} \mathrm{N} \\
151^{\circ} 53^{\prime} \mathrm{E}\end{array}$ & 22.5 & $\begin{array}{l}\text { Скв. 13, } \\
1018 \mathrm{cм}\end{array}$ & $\begin{array}{c}\text { Поздний плей- } \\
\text { стоцен - голо- } \\
\text { цен }\end{array}$ & 137 & $\begin{array}{l}\text { Ложкин и др., 2010; } \\
\text { Минюк, Борходоев, } \\
2016\end{array}$ \\
\hline Чистое & То же & $\begin{array}{c}59^{\circ} 32.6^{\prime} \mathrm{N} \\
151^{\circ} 47.9^{\prime} \mathrm{E} \\
\end{array}$ & 6 & $\begin{array}{l}\text { Скв. } 1, \\
555 \mathrm{~cm}\end{array}$ & Голоцен & 104 & Эта работа \\
\hline Большое & $-\gg-$ & $\begin{array}{c}63^{\circ} 17.8^{\prime} \mathrm{N} \\
147^{\circ} 51.07^{\prime} \mathrm{E}\end{array}$ & 6 & $\begin{array}{l}\text { Скв. } 1, \\
439 \text { см }\end{array}$ & \begin{tabular}{|c|}
$\begin{array}{c}\text { Поздний плей- } \\
\text { стоцен - голо- } \\
\text { цен }\end{array}$ \\
\end{tabular} & 123 & То же \\
\hline Щучье & Якутия & $\begin{array}{r}63^{\circ} 21.1^{\prime} \mathrm{N} \\
140^{\circ} 59.4^{\prime} \mathrm{E}\end{array}$ & 6.1 & $\begin{array}{l}\text { Скв. } 1, \\
347 \mathrm{~cm}\end{array}$ & Голоцен & 95 & Burnatny et al., 2019 \\
\hline
\end{tabular}

Возраст озер от позднего плиоцена до голоцена. Большинство их образовано в конце плейстоцена голоцене. Материалы по стратиграфии осадков, литологии, возрастным датировкам, палинологии, диатомеям, органической геохимии, петромагнетизму, минералогии частично опубликованы (см. таблицу).

\section{МЕТОДИКА ИССЛЕДОВАНИЙ}

Бурение озер (кроме оз. Эльгыгытгын) проводилось модифицированным пробоотборником Ли- вингстона (Wright et al., 1984). Для геохимического анализа образцы отобраны равномерно по колонкам с интервалом отбора 2-10 см. Отдельные пробы отбирали из делювия в источниках сноса, коренных пород, озерных террас, пляжных отложений.

Химический состав отложений изучен методом рентгенофлуоресцентного анализа. Породообразующие и редкие элементы определены на рентгенофлуоресцентных спектрометрах S4 Pioneer (Германия), СРМ-25 (Россия) и VRA-30 (Германия). 
Относительное количество органического материала и карбонатов оценено по величине потерь при прокаливании (ППП) после прогрева проб до 500 и $1000^{\circ} \mathrm{C}$. При температуре $500^{\circ} \mathrm{C}$ происходит выгорание органического углерода, при более высоких температурах углерод освобождается из карбонатов (Heiri et al., 2001). Разница веса при двух температурах использована как показатель карбонатов.

Кроме распределения элементов по разрезам, анализировались различные геохимические индексы и отношения элементов, широко используемые при исследованиях осадочных образований - индекс химического изменения CIA(Chemical Index of Alteration), плагиоклазовый индекс изменения PIA (Plagioclase Index of Alteration), химический индекс выветривания CIW (Chemical Index of Weathering), химический индикатор изменения СРA (Chemical Proxy of Alteration):

$\mathrm{CIA}=\left[\mathrm{Al}_{2} \mathrm{O}_{3} /\left(\mathrm{Al}_{2} \mathrm{O}_{3}+\mathrm{CaO}+\mathrm{NaO}+\mathrm{K}_{2} \mathrm{O}\right)\right] \times 100$ (Nesbitt, Young, 1982);

$\mathrm{PIA}=\left[\left(\mathrm{Al}_{2} \mathrm{O}_{3}-\mathrm{K}_{2} \mathrm{O}\right) /\left(\mathrm{Al}_{2} \mathrm{O}_{3}+\mathrm{CaO}+\mathrm{Na}_{2} \mathrm{O}-\right.\right.$ $\left.\left.\mathrm{K}_{2} \mathrm{O}\right)\right] \times 100$ (Fedo et al., 1995);

$\mathrm{CIW}=\left[\mathrm{Al}_{2} \mathrm{O}_{3} /\left(\mathrm{Al}_{2} \mathrm{O}_{3}+\mathrm{CaO}+\mathrm{Na}_{2} \mathrm{O}\right)\right] \times 100$ (Harnois, 1988);

$\mathrm{CPA}=\left[\mathrm{Al}_{2} \mathrm{O}_{3} /\left(\mathrm{Al}_{2} \mathrm{O}_{3}+\mathrm{Na}_{2} \mathrm{O}\right)\right] \times 100($ Buggle et al., 2010);

Индекс $\mathrm{B}=\left(\mathrm{CaO}+\mathrm{Na}_{2} \mathrm{O}+\mathrm{K}_{2} \mathrm{O}\right) /\left(\mathrm{Al}_{2} \mathrm{O}_{3}+\mathrm{CaO}+\right.$ $\mathrm{Na}_{2} \mathrm{O}+\mathrm{K}_{2} \mathrm{O}$ ) (Kronberg, Nesbitt, 1981);

$\mathrm{TiO}_{2} / \mathrm{Al}_{2} \mathrm{O}_{3}$ (Мигдисов, 1960);

$\mathrm{Al}_{2} \mathrm{O}_{3} / \mathrm{SiO}_{2}^{2}$ (Ронов, Мигдисов, 1965; Ruxton, 1968) и др.

Многие индексы и модули являются отношениями мобильных и немобильных (или наоборот) элементов, что позволяет оценить степень выветривания и химического изменения пород. В индексах CIA и PIA, используемых в работе, в качестве мобильных элементов задействованы Са (не карбонатный), Na и К. В индексах CIW, PIA калий отсутствует или вычитается, поскольку он как вымывается из пород при выветривании, так и накапливается. Обогащение пород калием происходит также в результате метасамотоза, приводящего к искажению индекса выветривания. В индексе СРА из мобильных элементов использован только натрий, кальций, как типичный элемент карбонатов, исключен.

Индексы, отношения и модули, вовлекающие в расчеты кремнезем, для оценки выветривания в источниках сноса по озерным осадкам непригодны из-за биогенного накопления кремния в озерах. По этой причине мы не использовали гидролизатный модуль $-\left(\mathrm{Al}_{2} \mathrm{O}_{3}+\mathrm{TiO}_{2}+\mathrm{Fe}_{2} \mathrm{O}_{3}+\mathrm{MnO}\right) / \mathrm{SiO}_{2}$ (Юдович, Кетрис, 2011), алюмокремниевый модуль $\mathrm{Al}_{2} \mathrm{O}_{3} / \mathrm{SiO}_{2}$ (Ронов, Мигдисов, 1965; Ruxton, 1968), силикатно-титановый индекс STI (Silica-Titania Index $)-\left[\left(\mathrm{SiO}_{2} / \mathrm{TiO}_{2}\right) /\left(\left(\mathrm{SiO}_{2} / \mathrm{TiO}_{2}\right)+\left(\mathrm{SiO}_{2} / \mathrm{Al}_{2} \mathrm{O}_{3}\right)+\right.\right.$ $\left.\left.\left(\mathrm{Al}_{2} \mathrm{O}_{3} / \mathrm{TiO}_{2}\right)\right)\right] \times 100$ (De Jayawardena, Izawa, 1994).

В работе уделено внимание анализу индексов CIA, PIA и параметра ППИ. Анализировались также отдельные элементы и отношения, включая $\mathrm{SiO}_{2} / \mathrm{TiO}_{2}, \mathrm{Fe}_{2} \mathrm{O}_{3} / \mathrm{TiO}_{2}, \mathrm{Al}_{2} \mathrm{O}_{3} /\left(\mathrm{Na}_{2} \mathrm{O}+\mathrm{CaO}\right)$, значение которых для озерного седиментогенеза приведено в соответствующих разделах.

Некоторые петрофизические характеристики осадков, такие как остаточная намагниченность насыщения Jrs, намагниченность насыщения Js, коэрцитивная сила Вc, остаточная коэрцитивная сила $\mathrm{Bcr}$, магнитная восприимчивость MS, использованы для интерпретации геохимических данных.

Палеоклиматические летописи древних озер охватывают несколько (оз. Гранд) или десятки (оз. Эльгыгытгын) морских изотопных стадий (МИС), показатели которых учитывались при восстановлении условий осадконакопления.

\section{РЕЗУЛЬТАТЫ ИССЛЕДОВАНИЙ И ОБСУЖДЕНИЕ}

Анализ геохимических данных, геохимическая зональность, выявленные закономерности распределения элементного состава по разрезам отдельных озер частично опубликованы: Эльгыгытгын (Минюк и др., 2003, 2007, 2011a; Minyuk et al., 2014), Джульетта (Minyuk et al., 2007), Гранд (Минюк, Борходоев, 2016), Пернатое (Anderson et al., 2015), Щучье (Burnatny et al., 2019). В данной работе рассмотрены отдельные элементы, отношения и индексы, связанные с ними.

$\mathrm{SiO}_{2}$. Содержание кремнезема в озерных осадках зависит от источников сноса и биологической продуктивности озера. «Высокие содержания $\mathrm{SiO}_{2}$, превышаюшие 75\%, встречаются только в двух типах осадочных пород - терригенных квариевых псаммитах и псефитах, типичных рециклизованных породах типа second cycle и в биогенных кремнистых породах - силиuзитах» (Юдович, Кетрис, 2011. С. 59). Основными поставщиками биогенного кремнезема (или опала) являются диатомовые водоросли, губки, использующие кремний в скелетах.

Источники сноса и озерные осадки в дальневосточном регионе характеризуются различными концентрациями $\mathrm{SiO}_{2}$. Низкие фоновые содержания кремнезема (без биогенной компоненты) свойственны осадкам Курильских озер, источниками сноса для которых являются продукты разложения основных пород. Материал, поступающий в озера из зон распространения кислых вулканитов Охотско-Чукотского пояса, характеризуется более высокими содержаниями $\mathrm{SiO}_{2}$. Полного соответствия содержаний кремния в вулканитах и осадках не может быть, так как осадки - это уже химически измененный материал. Специальные исследования различных фракций делювия по риолитам и их туфам со склонов сопок вблизи оз. Гранд показали направленные потери кремнезема с уменьшением размера гранулометрических фракций (Минюк, Борходоев, 2016). Во фракциях делювия 20 и 1 мкм потери $\mathrm{SiO}_{2}$ составляют соответственно 1-15 и 15-25\%. 
Для относительного содержания биогенного кремнезема в озерных осадках часто используется отношение $\mathrm{SiO}_{2} / \mathrm{TiO}_{2}$ (Tanaka et al., 2007; Brown, 2011; Melles et al., 2012; Adamson et al., 2019). Содержание биогенного кремнезема можно рассчитать по формуле: $\mathrm{SiO}_{2 \text { (bio) }}=\mathrm{SiO}_{2 \text { (total) }}-\mathrm{x}$ $\mathrm{Al}_{2} \mathrm{O}_{3}$, где $\mathrm{x}=\mathrm{SiO}_{2 \text { (d) }} / \mathrm{Al}_{2} \mathrm{O}_{3 \text { (d) }}$ детритового материала источника сноса (Leinen et al., 1977; Bertrand et al., 2008). Хемогенное накопление в бассейне карбонатов, оксидов и гидроксидов железа, марганца искажает общее содержание кремнезема и, следовательно, биогенного кремнезема в озерных осадках. Следует иметь в виду, что отношение $\mathrm{SiO}_{2(\mathrm{~d})} / \mathrm{Al}_{2} \mathrm{O}_{3(\mathrm{~d})}$ - величина не постоянная и зависит от степени химического изменения материала. В процессе выветривания пород, кроме потери кремнезема, происходит обогащение глиноземом. Самые высокие концентрации глинозема и низкие содержания кремнезема характерны для тонких алеврито-глинистых фракций выветрелых пород (Von Eynatten et al., 2012; Минюк, Борходоев, 2016). Это обстоятельство позволяет использовать отношение $\mathrm{SiO}_{2} / \mathrm{Al}_{2} \mathrm{O}_{3}$ как индекс выветривания (Ронов, Мигдисов, 1965; Ruxton, 1968), а в отсутствие биогенного накопления - как показатель привноса силикластики в бассейн (Bessa et al., 2018) или как гранулометрический показатель (Minyuk et al., 2014).
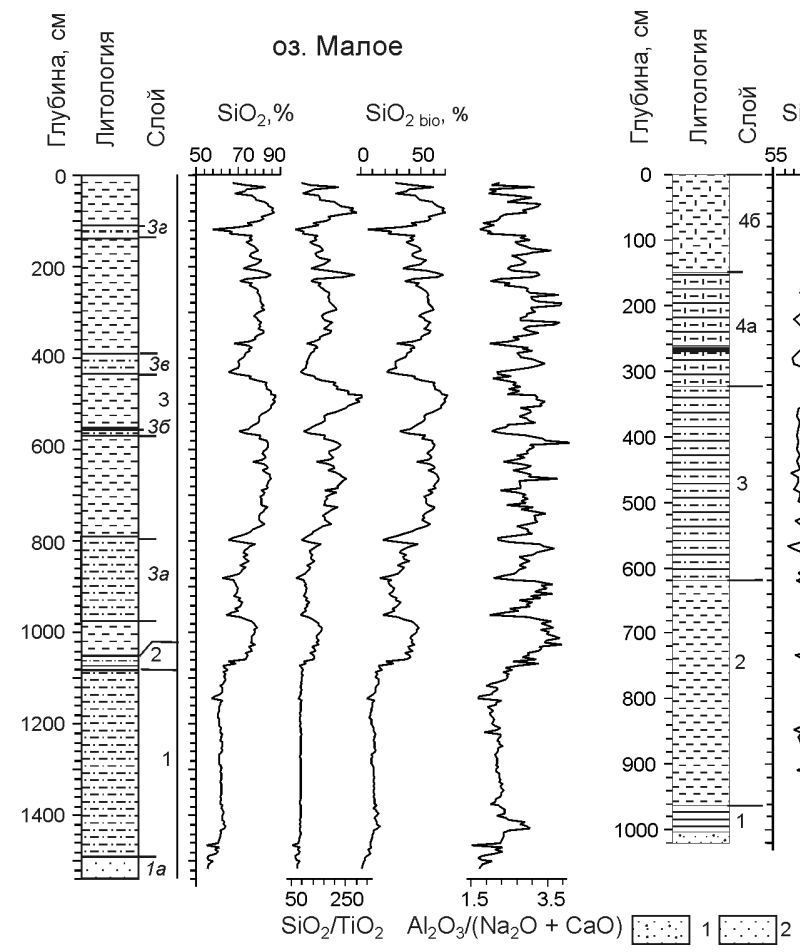

оз. Гранд
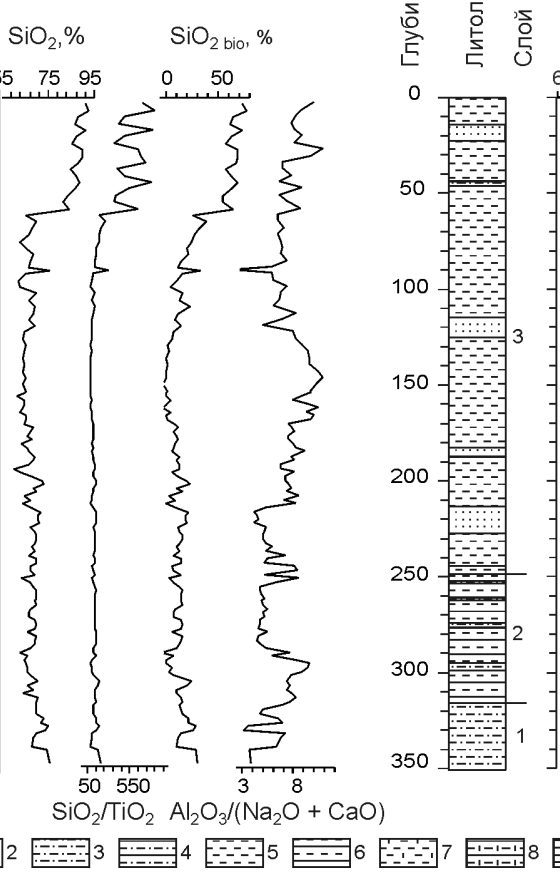

Рассмотрим наиболее типичные распределения терригенного и биогенного кремнезема в дальневосточных озерах.

Оз. Малое, о. Итуруп. Скважиной, пробуренной из центральной части озера, вскрыты три литологических слоя, характеризующих морские (слой 1), лагунные (слой 2) и озерные (слой 3) фации. Содержание $\mathrm{SiO}_{2}$ варьирует по разрезу от 55.24 до $87.56 \%$ (рис. 2). Минимальные значения $\mathrm{SiO}_{2}$ отмечены для слоя 1 (среднее $61.3 \%$ ). Его отложения характеризуются низким содержанием диатомей преимущественно морских видов. Для слоя 3 значения $\mathrm{SiO}_{2}$ составляют 57.99-87.56\% (среднее 77.3\%). Пониженные концентрации кремнезема в нем свойственны алевритистым пескам и песчаным алевритам. Высокие содержания $\mathrm{SiO}_{2}$ в слое отражают этапы накопления биогенного опала, связанного с диатомеями. Концентрации диатомовых створок максимальны в осадках слоев 2 и 3 (Lozhkin et al., 2017).

Геохимические данные отложений слоя $1 \mathrm{a}$, представленные несортированными песками с гравием (6 образцов), наиболее близко соответствуют характеристике источников сноса. Согласно классификационным диаграммам эти отложения имеют базальтово-андезитовый состав. Средние концентрации $\mathrm{SiO}_{2}$ и $\mathrm{Al}_{2} \mathrm{O}_{3}$ для них составляют соответственно 56.11 и $18.06 \%$. Эти данные использованы для расчетов биогенного

Рис. 2. Распределение $\mathrm{SiO}_{2}, \mathrm{SiO}_{2 \text { bio }}, \mathrm{SiO}_{2} / \mathrm{TiO}_{2}, \mathrm{Al}_{2} \mathrm{O}_{3} /\left(\mathrm{Na}_{2} \mathrm{O}+\mathrm{CaO}\right)$ в осадках оз. Малое, Гранд, Щучье: 1 - песок с гравием; 2 - песок; 3 (4) - массивный (слоистый) алеврит; 5 (6) - массивный (слоистый) песчаный алеврит; 7 (8) - органогенный массивный (слоистый) алеврит; 9 - глина; 10 - торфяник; 11 - тефра

Fig. 2. Distribution of $\mathrm{SiO}_{2}, \mathrm{SiO}_{2 \text { bio, }}, \mathrm{SiO}_{2} / \mathrm{TiO}_{2}, \mathrm{Al}_{2} \mathrm{O}_{3} /\left(\mathrm{Na}_{2} \mathrm{O}+\mathrm{CaO}\right)$ in sediments of Lake Maloye, Lake Grand, and Lake Shchuchye: 1 - sand with gravel; 2 - sand; 3 (4) - massive (laminated) silt; 5 (6) - massive (laminated) sandy silt; 7 (8) - organogenic massive (laminated) silt; 9 - clay; 10 - peat; 11 - tephra 
кремнезема. Вычисленные содержания $\mathrm{SiO}_{2 \text { (bio) }}$ в осадках оз. Малое варьируют в пределах 1-72\% (среднее 35\%). Самые большие значения этого показателя отмечены для слоя 3 в интервалах глубин 60-90, 215-225, 455-520 см, что указывает на экстремально высокую биопродуктивность бассейна во время их накопления (см. рис. 2).

Отношение $\mathrm{SiO} / \mathrm{TiO}_{2}$ составляет 55.8-312.7 (среднее 138.9). Кривая распределения $\mathrm{SiO}_{2} / \mathrm{TiO}_{2}$ по разрезу повторяет ход кривых содержаний общего и биогенного кремнезема.

Оз. Гранд. В осадочном разрезе оз. Гранд выделены 4 литологические единицы: слой 1 (гл. 965 см - основание), глины, алевриты, дресва; слой 2 (гл. 627-965 см), массивные неслоистые алевриты; слой 3 (гл. 320-627 см), слоистые алевриты; слой 4 (гл. 0-320 см), органогенные слоистые (4a) и неслоистые (4б) алевриты (см. рис. 2).

Согласно радиоуглеродным и палинологическим данным отложения сформированы в течение морских изотопных стадий (МИС) 4 (слой 1), 3 (слой 2), 2 (слой 3 ) и 1 (слой 4) (Ложкин и др., 2010; Минюк, Борходоев, 2016).

Содержание $\mathrm{SiO}_{2}$ варьирует в осадках озера от 59.91 до 92.44\% (среднее 70.06\%). Резкое увеличение концентраций кремнезема отмечено в голоценовых осадках, начиная с глубины 170 см. Отношение $\mathrm{SiO}_{2} / \mathrm{TiO}_{2}$ изменяется по разрезу параллельно изменениям общего кремнезема, составляя 81.4-840.4 (среднее 185.6). При расчете биогенного кремнезема использованы концентрации $\mathrm{Al}_{2} \mathrm{O}_{3}$ и $\mathrm{SiO}_{2}$ для тонких фракций делювия со склонов сопок, в которых средние содержания $\mathrm{Al}_{2} \mathrm{O}_{3}$ и $\mathrm{SiO}_{2}$ равны соответственно 20.65 и 65.82\%. Вычисленные содержания $\mathrm{SiO}_{2 \text { (bio) }}$ в осадках о3. Гранд варьируют в пределах 4.16-76.50\% (среднее $18.28 \%$ ) с максимальными значениями в верхней части голоценовых отложений (слой 4б).

Оз. Щучье. Осадки озера объединены в 3 слоя: слой 1 (гл. 315-347 см), массивные песчаные алевриты с прослоями песков; слой 2 (гл. 250315 см), слоистые алевриты с прослоями песчаных алевритов и слой 3 (гл. 0-250 см), массивные алевриты с прослоями песчаных алевритов (см. рис. 2). Геохимические характеристики отложений контролируются литологией. Содержание $\mathrm{SiO}_{2}$ составляют 63.45-76.62\% (среднее 69.42\%). Кремнезем позитивно коррелирует только с натрием ( $\mathrm{r}=0.79)$, цирконием $(\mathrm{r}=0.57)$ и стронцием $(\mathrm{r}=0.49)$. Максимальные содержания этих элементов характерны для грубозернистых разностей. В отличие от осадков Курильских озер и многих озер Магаданской области грубозернистые отложения оз. Щучье практически не магнитные, со значениями магнитной восприимчи-

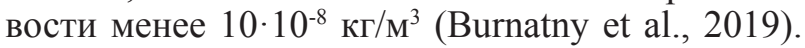
Они преимущественно кварцевые и по магнитным и геохимическим характеристикам не отличаются от гальки, собранной в окрестностях озера. Отношение $\mathrm{SiO}_{2} / \mathrm{TiO}_{2}$ подчеркивает рас- пределение $\mathrm{SiO}_{2}$. Повышенные значения этих параметров характерны для отложений слоя 1 (гл. 315-347 см), а также интервалов глубин 213-225, 112-124 и 15-22 см. Анализ слайдов показывает, что во всех прослоях, обогащенных $\mathrm{SiO}_{2}$, диатомей нет или они единичны.

Грубозернистость отложений слоя 1 обусловлена обильным поступлением обломочного кварцевого материала в начале образования озера, верхние горизонты отражают этапы интенсивного привноса силикластики, связанные, видимо, с наводнениями. Отметим, что оз. Щучье слабопроточное, его водный баланс зависит от более крупного оз. Улу, расположенного гипсометрически выше и с которым оно соединяется протокой. Материал мог как поступать со склонов, так и приноситься протокой.

Таким образом, оз. Щучье является типичным представителем озерного детритового седиментогенеза. К этому типу относятся также о3. Чистое и Большое. Озера Курильских островов характеризуются интенсивным биогенным накоплением кремнезема, причем максимальным в пресноводных условиях. Согласно радиоуглеродным датировкам, смена условий седиментогенеза с преимущественно детритового на биогенное произошла во второй половине голоцена после морской трансгрессии около 5200 лет (оз. Пернатое), 6200 лет (оз. Малое) (Anderson et al., 2015; Lozhkin et al., 2017). Из-за недостаточного количества радиоуглеродных определений региональная возрастная корреляция этого события затруднена. Тем не менее в оз. Гранд, по данным диатомового анализа осадков скв.1, резкий всплеск биологической продуктивности отмечен во второй половине голоцена между 5000 и 6000 л. н. (Ложкин и др., 2010; Черепанова и др., 2013).

$\mathrm{Al}_{2} \mathrm{O}_{3}, \mathrm{CaO}, \mathrm{Na}_{2} \mathrm{O}, \mathbf{K}_{2}$ O. Эти оксиды, как уже указывалось, используются в различных индексах и модулях для оценки степени химического изменения (выветривания пород). Алюминий считается немобильным, в то время как $\mathrm{Ca}, \mathrm{Na}$ и К подвижные и выносятся из продуктов выветривания. Отношения немобильных к мобильным элементам (и наоборот) будут отражать, с одной стороны, степень химического изменения материала, с другой - его гранулометрический размер. Как гранулометрический показатель подобные отношения будут справедливы при условии детритового происхождения анализируемых элементов. В солоноватых и соленых озерах аридного климата происходит хемогенное накопление подвижных $\mathrm{Ca}, \mathrm{Na}, \mathrm{K}$, приносимых поверхностными и подземными водами. Как правило, общая минерализация воды в таких озерах высокая. Например, в воде оз. Баркол, геохимические данные осадков которого использованы для расчета индексов химического изменения, содержание катионов $\mathrm{Ca}^{+}, \mathrm{Na}^{+}$и $\mathrm{K}^{+}$составляет 444.8, 62089.39 
и 1117.35 мг/л соответственно (Zhong et al., 2012). В олиготрофных озерах Северо-Востока России общая минерализация вод низкая. Концентрации $\mathrm{Ca}^{+}$и $\mathrm{Na}^{+}$и $\mathrm{K}^{+}$составляют: $3.67,1.91,0.28 \mathrm{мг/л}$ (оз. Гранд); 5.19, 1.04 и 0.34 мг/л (оз. Большое); $5.46,4.86$ и 0.42 мг/л (оз. Чистое). Вода с такими содержаниями катионов не будет влиять на геохимические характеристики осадков.

Относительный размер зерен озерных осадков оценен по отношению $\mathrm{ACN}=\mathrm{Al}_{2} \mathrm{O}_{3} /(\mathrm{CaO}+$ $\mathrm{Na}_{2} \mathrm{O}$ ). Оксиды $\mathrm{CaO}$ и $\mathrm{Na}_{2} \mathrm{O}$ использованы вместо $\mathrm{SiO}_{2}$, чтобы исключить влияние биогенного кремнезема. Большие значения отношения характерны для тонких гранулометрических разностей осадков. Рассмотрим характерные распределения отношения ACN в осадках некоторых озер.

Оз. Малое. Для осадков озера оксиды $\mathrm{CaO}$ и $\mathrm{Na}_{2} \mathrm{O}$ позитивно коррелируют между собой $(\mathrm{r}=0.93)$. Коэффициенты корреляции между $\mathrm{Al}_{2} \mathrm{O}_{3}$ и $\mathrm{CaO}$ равны $0.90, \mathrm{Al}_{2} \mathrm{O}_{3}$ и $\mathrm{Na}_{2} \mathrm{O}-0.95$. Отношение $\mathrm{Al}_{2} \mathrm{O}_{3} /\left(\mathrm{CaO}+\mathrm{Na}_{2} \mathrm{O}\right)$ для отложений слоя 1а составляет 1.7-2.0 (среднее 1.8), слоя 1 1.53-3.05 (среднее 2.23), слоя 2 - 2.41-3.27 (среднее 2.81), слоя $3-1.75-4.17$ (среднее 2.89) (см. рис. 2). Минимальные значения характерны для песков и гравия слоя 1а, наименее химически измененных. Сильные вариации гранулометрического состава отмечены для отложений слоя 3. В слое, кроме визуально видимых прослоев алевритистых песков и песчаных алевритов, по этому параметру выделяется ряд пиков, соответствующих, видимо, различным гранулометрическим разностям и фиксирующих ритмичный процесс осадконакопления (см. рис. 2). ACN позитивно коррелирует только с $\mathrm{SiO}_{2}$ и $\mathrm{SiO}_{2 \text { (bio). }}$ Для осадочного разреза оз. Малое пики ACN совпадают с пиками $\mathrm{SiO}_{2 \text { (bio) }}$ и $\mathrm{SiO}_{2} / \mathrm{TiO}_{2}$. Коэффициенты корреляции $\mathrm{ACN}$ с $\mathrm{SiO}_{2}$ (біо и $\mathrm{SiO}_{2} / \mathrm{TiO}_{2}$ составляют соответственно 0.63 и 0.58 . Биогенный кремнезем в этом бассейне во время голоцена больше накапливался при поступлении тонкого детритового материала.

Оз. Гранд. История его развития охватывает несколько изотопных стадий, осадки которых гранулометрически различаются. В целом они алеврито-глинистой размерности. Ситование проб показало, что массивные алевриты МИСЗ (слой 2) и, частично, МИС1 (слой 4) более грубые и включают до $2 \%$ зерен размером более 40 мкм, в то время как слоистые осадки (МИС2, слой 1,3 и МИС 4 , слой 1) содержат $0.06-0.2 \%$ таких же зерен. Отношение ACN для всего разреза составляет 2.15-10.82 (среднее 7.0). Пониженные значения этого параметра (более грубые отложения) характерны для отложений теплых климатических стадий. Предполагается, что климат, контролирующий ледовый покров на озере, и условия транспортировки материала в бассейн и распределение его по площади озера были глав- ными причинами, обусловившими гранулометрическое различие осадков теплых и холодных стадий (Минюк, Борходоев, 2016). Подобная закономерность установлена в осадках оз. Эльгыгытгын, охватывающих десятки климатических стадий (Francke et al., 2013; Minyuk et al., 2014). Коэффициент корреляции $\mathrm{ACN}$ и $\mathrm{SiO}_{2 \text { (bio) }}$ для голоценовой части разреза (слой 1) отсутствует $(\mathrm{r}=-0.004)$, в то время как для осадков МИС2 МИС4 составляет -0.74 .

Максимальные значения ACN отмечены для отложений МИС2 (слой 3) в интервале глубин 390-450 см, что может отражать этап ледникового максимума (см. рис. 2).

Оз. Щучье является типичным представителем водного бассейна детритового осадконакопления. Распределение алюминия по разрезу составляет 13.38-19.35 и находится в противофазе с кремнеземом. Алюминий значимо отрицательно коррелирует с $\mathrm{Na}_{2} \mathrm{O}(\mathrm{r}=-0.90)$, но положительно с $\mathrm{CaO}(\mathrm{r}=0.32)$. Коэффициент корреляции $\mathrm{Na}_{2} \mathrm{O}$ и $\mathrm{CaO}$ составляет -0.35 . Предполагается, что часть кальция связана с карбонатными породами, принесенными ледником.

Отношение ACN варьирует по разрезу в пределах 3.77-8.84, следуя гранулометрическому размеру зерен. Низкие значения отношения маркируют грубые разности осадков, обогащенные, как указывалось, кремнеземом. Коэффициенты корреляции $\mathrm{ACN}$ и $\mathrm{SiO}_{2}$ и $\mathrm{ACN}$ и $\mathrm{SiO}_{2} / \mathrm{TiO}_{2}$ составляют соответственно -0.75 и -0.83 .

Таким образом, отношение ACN является информативным геохимическим показателем гранулометрии озерных осадков, что важно для седиментологических реконструкций. Как правило, грубые осадки в озерах находятся вблизи устьев ручьев. Площади водосбора, атмосферные осадки, энергия водотоков являются главными факторами, контролирующими транспортировку и сортировку материала.

\section{ИНДЕКСЫ СIA, PIA}

Индексы являются показателями химического изменения пород, которое более интенсивно при теплом и влажном климате (Nesbitt, Young, 1982). Породообразующие минералы по-разному изменяются в процессе химического выветривания. Например, из минеральных компонентов гранитов наиболее подвержены выветриванию плагиоклазы, затем щелочные полевые шпаты, наиболее стойким является кварц (Nesbitt et al., 1996).

О тренде выветривания можно судить по диаграммам $A-C N-K\left[\mathrm{Al}_{2} \mathrm{O}_{3}-\left(\mathrm{CaO}+\mathrm{Na}_{2} \mathrm{O}\right)-\right.$ $\left.\left.\mathrm{K}_{2} \mathrm{O}\right], A K-C-N\left[\left(\mathrm{Al}_{2} \mathrm{O}_{3}-\mathrm{K}_{2} \mathrm{O}\right)-\mathrm{CaO}-\mathrm{Na}_{2} \mathrm{O}\right)\right]$, $A-C N K-F M\left[\mathrm{Al}_{2} \mathrm{O}_{3}-\left(\mathrm{CaO}+\mathrm{Na}_{2} \mathrm{O}+\mathrm{K}_{2}^{2} \mathrm{O}-\right.\right.$ $\left.\left(\mathrm{Fe}_{2} \mathrm{O}_{3}+\mathrm{MgO}\right)\right]$, в которых оксиды приводятся в молярных пропорциях (Nesbitt, Young, 1984; Fedo et al., 1995; Nesbitt et al., 1996). Так как железо в озерах может осаждаться из растворов, перераспределяться и концентрироваться в аути- 
генных минералах, $A-C N K-F M$ диаграмму при анализе озерных осадков мы не использовали. В ряду выветривания важное значение имеют геохимические данные по источникам сноса, особенно по неизмененным породам, что позволяет устанавливать связь между ними и осадками. Индекс СІА для неизмененных базальтов, гранитов и гранодиоритов составляет 30-45 и 45-55 соответственно (Nesbitt, Young, 1982). Эти породы будут локализованы в нижней части $A-$ $C N-K$ диаграмм. Вершину треугольника занимают хлорит, каолинит, гибсит, промежуточное положение - смектит и иллит. Неизмененные породы имеют индекс PIA около 50, хлорита, каолинита, гибсита - 100 (Fedo et al., 1995).

Грубозернистые разности озерных отложений наиболее близко будут соответствовать материнским породам, хотя пески и гравий, галька - это уже химически измененный материал, в котором часть подвижных элементов потеряна (Nesbitt et al., 1996).

Рассмотрим тренд химического выветривания по материалам оз. Эльгыгытгын, где состав коренных пород разнообразный (Minyuk et al., 2014). В окрестностях озера доминируют кислые меловые породы эргываамской и пыкарваамской свит, подчиненное значение имеют вороньинская и коэквуньская свиты андезитового и андезибазальтового составов. Анализировались геохимические данные коренных пород, разнородной гальки пляжа, озерных осадков. Линия тренда на диаграмме $A-C N-K$ субпараллельна стороне треугольника $\left(\mathrm{CaO}+\mathrm{Na}_{2} \mathrm{O}\right)-\mathrm{Al}_{2} \mathrm{O}_{3}$ (рис. $\left.3, a\right)$, что указывает на преимущественную потерю $\mathrm{CaO}$ и $\mathrm{Na}_{2} \mathrm{O}$ по сравнению с калием. СІА озерных осадков составляет 60-75. Вблизи линии тренда в нижней части диаграммы находятся породы эргываамской и пыкарваамской свит, которые являются главными источниками детритового материала в озеро. Породы этих свит химически неизмененные, они расположены около линии плагиоклаз - калиевый полевой шпат. Галька занимает промежуточное положение между коренными породами и озерными осадками. Кластеры вороньинской и коэквунской свит находятся в стороне от линии тренда, указывая на то, что продукты выветривания этих пород вносят незначительный вклад в процесс осадконакопления. При анализе источников поступления детритового материала в озеро рассматривалась возможность эолового привноса материала из отдаленных районов. Использованы геохимические данные по едомным отложениям. На диаграмме $A-C N-$ $K$ они расположены отдельной группой, обогащены кальцием и натрием и химически менее изменены по сравнению с озерными осадками.

Линия тренда на $A K-C-N$ диаграмме субпараллельна оси $\left(\mathrm{Al}_{2} \mathrm{O}_{3}-\mathrm{K}_{2} \mathrm{O}\right)-\mathrm{Na}_{2} \mathrm{O}$, что говорит о преимущественной потере натрия над калием (см. рис. 3, б). Озерные осадки, галька и кис- лые вулканиты расположены вдоль линии тренда, в стороне от нее - ореолы коэквуньской, вороньинской и едомной свит. В целом полученные материалы указывают на связь озерных осадков с кислыми породами эргываамской и пыкарваамской свит.

Характер $A-C N-K$ и $A K-C-N$ диаграмм о3. Гранд во многом аналогичен таковому оз. Эльгыгытгын (рис. 3, в, г). При построении использованы геохимические данные озерных осадков и делювия, отобранного со склонов близлежащих сопок. Пробы делювия представляют собой продукты выветривания риолитов и их туфов. Каждая проба разделена на фракции 2500, 500, 250, $140,100,63,40,20$ и 1 мкм. На диаграммах ореолы тонких фракций делювия (20 и 1 мкм) расположены в вытянутой области озерных осадков. Более грубые фракции делювия, менее измененные, занимают нижние части диаграмм. Индексы CIA и PIA составляют около 60. По сравнению с кислыми вулканитами о3. Эльгыгытгын эти породы более измененные.

Подобные линии тренда выветривания имеют осадки оз. Чистое (CIA $=60-75$, PIA $=62-75)$, Большое $($ CIA $=60-75$, PIA $=65-80)$, Щучье $($ CIA $=60$ 70 , PIA $=65-80)-$ на $A-C N-K$ и $A K-C-N$ диаграммах они субпараллельны сторонам треугольников $\left(\mathrm{CaO}+\mathrm{Na}_{2} \mathrm{O}\right)-\mathrm{Al}_{2} \mathrm{O}_{3}$ и $\mathrm{Na}_{2} \mathrm{O}-\left(\mathrm{Al}_{2} \mathrm{O}_{3}-\mathrm{K}_{2} \mathrm{O}\right)$.

Для осадков оз. Малое, представляющих литологические разности от грубозернистых песков и гравийников до алевритов, линия тренда на $A-C N-K$ диаграмме также субпараллельна стороне треугольника $\left(\mathrm{CaO}+\mathrm{Na}_{2} \mathrm{O}\right)-\mathrm{Al}_{2} \mathrm{O}_{3}$ (см. рис. $3, \partial$ ), что указывает на преимущественную потерю $\mathrm{CaO}$ и $\mathrm{Na}_{2} \mathrm{O}$ по сравнению с калием. Образцы на графике группируются ближе к плагиоклазовой области. Песчано-гравийные разности, наименее измененные, занимают положение вблизи линии плагиоклаз - калиевый полевой шпат.

Плагиоклазовый индекс изменения имеет близкие значения к СIA. В отличие от предыдущих $A K-C-N$ диаграмм, линия тренда субпараллельна стороне треугольника $\mathrm{CaO}-\left(\mathrm{Al}_{2} \mathrm{O}_{3}-\right.$ $\mathrm{K}_{2} \mathrm{O}$ ) (см. рис. 3, е). Кальций в осадках оз. Малое преобладает над натрием. Расположение образцов на диаграмме указывает на преимущественно анортитовый состав отложений. Потеря $\mathrm{CaO}$ при выветривании происходит быстрее $\mathrm{Na}_{2} \mathrm{O}$. Ореолы грубозернистых отложений находятся на одной линии с морскими, лагунными и озерными осадками. Такой тип диаграмм характерен для осадков всех изученных озер Курильского архипелага (Пернатое, Токатан), в которых кальций доминирует над натрием.

Анализ $A-C N-K$ и $A K-C-N$ диаграмм показывает, что в осадконакоплении изученных озер главную роль играет материал, поступающий с прилегающих территорий, хотя озерные котловины расположены на различных вулкани- 


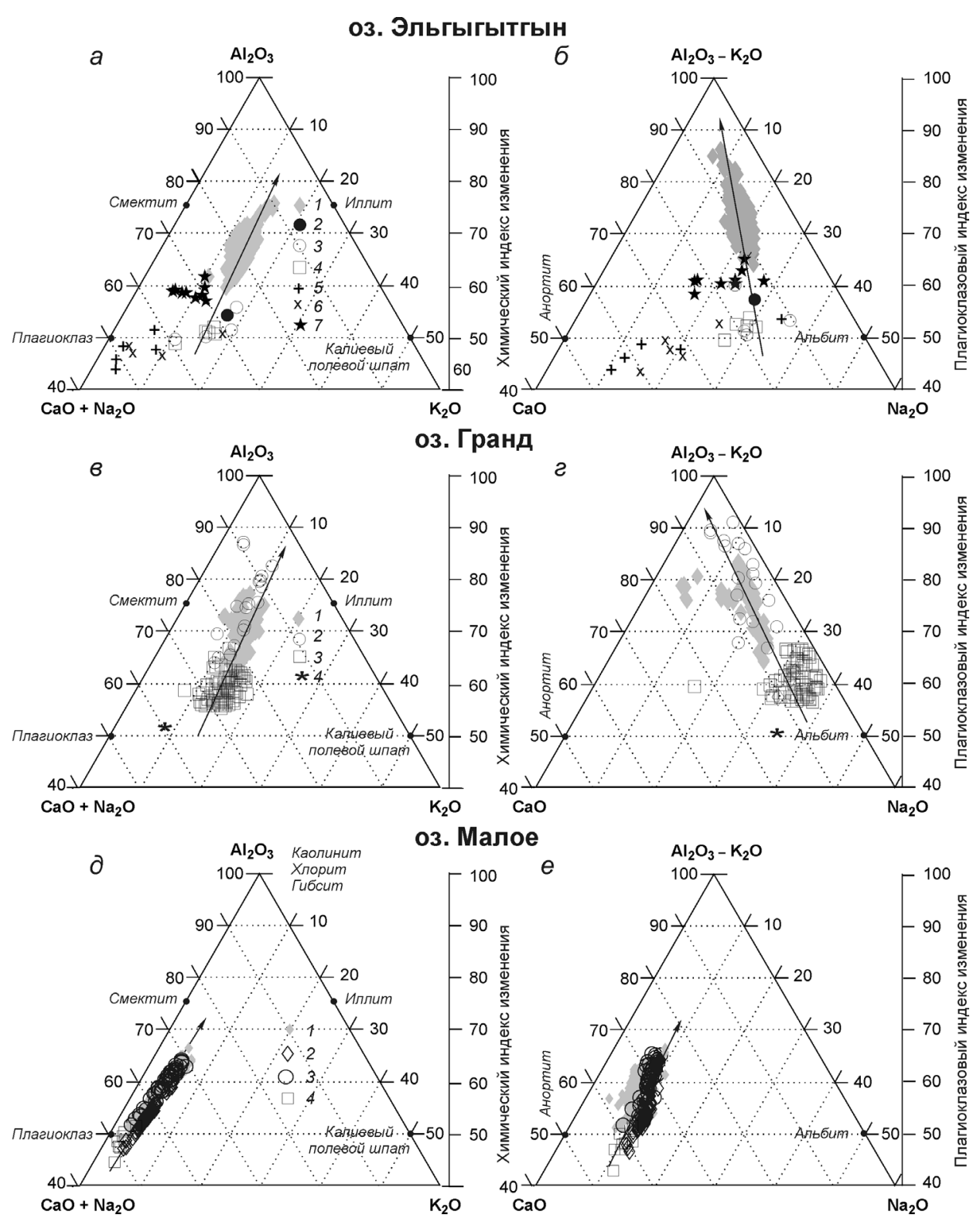

Puc. 3. Диаграммы, показывающие тренд выветривания коренных пород и осадков озер. Оз. Эльгыгытгын $(a$, б): 1 - озерные осадки; 2 - галька; 3 - пыкарваамская свита; 4 - эргываамская свита; 5 - вороньинская свита; 6 - коэквуньская свита; 7 - ледовый комплекс. Оз. Гранд $(8,2): 1$ - озерные осадки; 2 - делювий, фракции 1-20 мкм; 3 - делювий, фракции более 20 мкм; 4 - тефра. Оз. Малое $(\partial, e): 1$ - отложения прослоя 1а; 2 - отложения слоя 1; 3 -алевритистые пески и песчаные алевриты слоя 3; 4 - массивные и слоистые алевриты слоя 2 и 3

Fig. 3. Ternary diagrams showing weathering trends in rocks and lake sediments. Lake El'gygytgyn $(a, \sigma): 1-$ lake sediments; 2 - pebbles; 3 - Pykarvaam formation; 4 - Ergyvaam formation; 5 - Voronian formation; 6 - Koekvun' formation; 7 - ice complex. Lake Grand $(6,2): 1$ - lake sediments; 2 - talus, grain size 1-20 $\mu \mathrm{m} ; 3$ - talus, grain size $>20$ $\mu \mathrm{m} ; 4$ - tephra. Lake Maloye $(\partial, e): 1$ - sediments of unit 1a; 2 - sediments of unit $1 ; 3$ - sandy silts and silty sands of unit $3 ; 4$ - massive and laminated silt of unit 2 and 3

ческих и осадочных породах, во впадинах, выполненных рыхлыми осадочными образованиями (оз. Большое, Чистое), в ледниковых долинах со сложным осадочным чехлом.

Так как исследуемые озера закрытые или слабопроточные, водный привнос материала из отдаленных районов отсутствует. Однако в голоценовых осадках установлен вулканический пепел, который в отличие от осадков на $A-C N-K$ и $A K-C-N$ диаграммах занимает отдельное поло- жение, близкое к неизмененным породам риолитового состава (см. рис. 3, в, 2).

$\mathbf{F e}_{2} \mathbf{O}_{3}, \mathbf{T i O}_{2}, \mathbf{M n O}, \mathbf{P}_{2} \mathbf{O}_{5}$. Железо, марганец фосфор играют важную роль в озерном седиментогенезе (Юдович, Кетрис, 2011, 2014). Эти элементы являются показателями эвтрофикации озер. Они поступают в озера в виде детритового материала и растворенных форм. Осаждение железа и марганца из растворов контролируется окислительно-восстановительными условия- 
ми (редокс - reduction-oxidation). При постепенной смене восстановительной среды на окислительную первым осаждается железо, в то время как марганец находится еще в растворенной форме. Большие отношения $\mathrm{Fe} / \mathrm{Mn}$ будут указывать на восстановительные условия. При усилении окислительного процесса начинает выпадать из растворов марганец и, как следствие, отношение $\mathrm{Fe} / \mathrm{Mn}$ будет падать (Mackereth, 1966; Davison, 1993). Как показатель редокса, отношение $\mathrm{Fe} / \mathrm{Mn}$ $(\mathrm{Mn} / \mathrm{Fe})$ широко используется при исследованиях озер различного генезиса и возраста (Melles et al., 2012; Frugone-Álvarez et al., 2017; Bulkan et al., 2018; Adamson et al., 2019). Некоторые ограничения связаны с асидификацией бассейна, приводящей к уменьшению марганца, сульфидизацией, мобилизирующей железо. Однако главным условием является наличие растворенных форм этих элементов, так как в продуктах чисто физической эрозии отношение элементов будет, как в источниках сноса (Mackereth, 1966).

Для оценки вклада недетритового железа в общее использовано отношение железа к титану. При минералогическом поступлении железа в бассейн отношение изменяется незначительно (Reynolds et al., 2004; Brunscho et al., 2010). Значения отношения ниже фоновых могут свидетельствовать о растворении железосодержащих минеральных фаз и выносе железа (Fey et al., 2009). Кроме показателя редокса, анализ распределения отношения $\mathrm{Fe}_{2} \mathrm{O}_{3} / \mathrm{TiO}_{2}$ использован для оценки источников сноса (Левитан и др., 2012), антропогенового загрязнения водоемов (Cvetkoska et al., 2014).

По преимущественному генезису железа и марганца в осадках дальневосточные озера можно разделить на несколько групп.

Голоиеновые прибрежно-морские озера Курильских островов (Пернатое, Малое, Токатан). Железо и марганец в осадках имеют преимущественно детритовое происхождение. Содержания $\mathrm{Fe}_{2} \mathrm{O}_{3}$ варьируют в пределах 4.31-20.73\% (оз . Пернатое), $8.91-10.53 \%$ (оз. Малое), 3.94-16.53\% (оз. Токатан). Содержание $\mathrm{MnO}$ составляет 0.06$0.38 \%$ (оз. Пернатое), $0.11-0.16 \%$ (оз. Малое), $0.07-0.36 \%$ (оз. Токатан).

Индикаторы детритового железа можно проследить на примере осадков оз. Пернатое (Минюк и др., 2013; Anderson et al., 2015). В разрезе скважины, пробуренной из центральной части озера, выделяются три литологических слоя: слой 1 (гл. 646-696 см), плотный бурый торф; слой 2 (гл. 429-646 см), в нижней части гомогенный массивный алеврит, в верхней - песчанистый алеврит; слой 3 (гл. 0-429 см), песчаный алеврит с прослоями черного тонкозернистого песка.

Максимальные значения железа в осадках имеют грубозернистые разности - пески, алевритистые пески, песчаные алевриты. Основная масса железа сконцентрирована в ферромагнитных минералах - магнетитах, титаномагнетитах, что подтверждается значимой положительной корреляцией железа с магнитной восприимчивостью $(\mathrm{MS})-\mathrm{r}=0.63$. Корреляция парамагнитной восприимчивости с железом низкая $(\mathrm{r}=0.18)$. $\mathrm{TiO}_{2}$ положительно коррелирует с $\mathrm{Fe}_{2} \mathrm{O}_{3}(\mathrm{r}=0.96)$.

В осадках оз. Пернатое независимо от гранулометрического состава отношение $\mathrm{Fe}_{2} \mathrm{O}_{3} / \mathrm{TiO}_{2}$ изменяется незначительно - от 12.02 до 16.02 (среднее 9.88), хотя распределение железа и титана сильно варьирует по разрезу (рис. 4). На глубине 0-195 см средние значения $\mathrm{Fe}_{2} \mathrm{O}_{3}$ и $\mathrm{TiO}_{2}$ составляют 13.28 и $1.25 \%$, в то время как на глубине 195-700 см среднее значение $\mathrm{Fe}_{2} \mathrm{O}_{3}$ равняется $7.05 \%$, а $\mathrm{TiO}_{2}-0.61 \%$. Марганец в осадках оз. Пернатое, как и в других исследованных озеpax Курильского архипелага, также имеет преимущественно детритовое происхождение. Отмечается очень высокая корреляция этого элемента с железом $(\mathrm{r}=0.96)$, что могло бы свидетельствовать о хемогенном генезисе марганца. Однако $\mathrm{MnO}$ положительно коррелирует с детритовыми элементами $-\mathrm{TiO}_{2}(\mathrm{r}=0.92), \mathrm{MgO}(\mathrm{r}=0.99), \mathrm{CaO}$ $(\mathrm{r}=0.80)$, а также с MS (r=0.67), остаточной намагниченностью насыщения $(\mathrm{r}=0.76)$, намагниченностью насыщения $(\mathrm{r}=0.74)$. Фосфор не коррелирует ни с железом $(\mathrm{r}=-0.15)$, ни с марганцем $(\mathrm{r}=-0.17)$.

Плейстоиен-голоиеновое оз. Гранд. В осадках озера железо имеет детритовый и хемогенный генезис. Корреляция железа с магнитной восприимчивостью слабая отрицательная $(\mathrm{r}=-0.20)$, однако она значимая положительная с парамагнитной восприимчивостью $(\mathrm{r}=0.96)$, что указывает на связь этого элемента с железосодержащими немагнитными минералами, включая аллогенные и аутигенные формы. Слабая положительная корреляция $\mathrm{Fe}_{2} \mathrm{O}_{3}$ и $\mathrm{TiO}_{2}(\mathrm{r}=0.29)$ подтверждает частичное детритовое происхождение железа. Содержания $\mathrm{Fe}_{2} \mathrm{O}_{3}$ и $\mathrm{TiO}_{2}$ в отложениях оз. Гранд сильно варьируют по колонке, составляя соответственно $1.01-18.07$ и $0.11-0.77 \%$. Отношение $\mathrm{Fe}_{2} \mathrm{O}_{3} / \mathrm{TiO}_{2}$ изменяется в осадках в широком диапазоне - от 5.21 до 55.11 (см. рис. 4). Максимальные значения этого параметра характерны для голоценовых осадков с глубины 160230 см (Минюк, Борходоев, 2016). Пики отношения зафиксированы также в зеленовато-черных прослоях отложений холодной морской изотопной стадии (МИС) 2 и в холодных интервалах стадии МИСЗ. Этим пикам свойственны повышенные значения марганца и фосфора. Отмечена значимая корреляция $\mathrm{Fe}_{2} \mathrm{O}_{3}$ и $\mathrm{MnO}(\mathrm{r}=0.87)$, $\mathrm{Fe}_{2} \mathrm{O}_{3}$ и $\mathrm{P}_{2} \mathrm{O}_{5}(\mathrm{r}=0.78), \mathrm{P}_{2} \mathrm{O}_{5}$ и $\mathrm{MnO}(\mathrm{r}=0.91)$. Выявленные аномалии отношения $\mathrm{Fe}_{2} \mathrm{O}_{3} / \mathrm{TiO}_{2}$ представляют палеоредокс слои. Максимальные пики содержания $\mathrm{Fe}_{2} \mathrm{O}_{3}$ совпадают с минимумами отношения $\mathrm{Fe}_{2} \mathrm{O}_{3} / \mathrm{MnO}$, что является признаком восстановительных условий (Davison, 1993). Железо в этих прослоях концентрировалось в желе- 


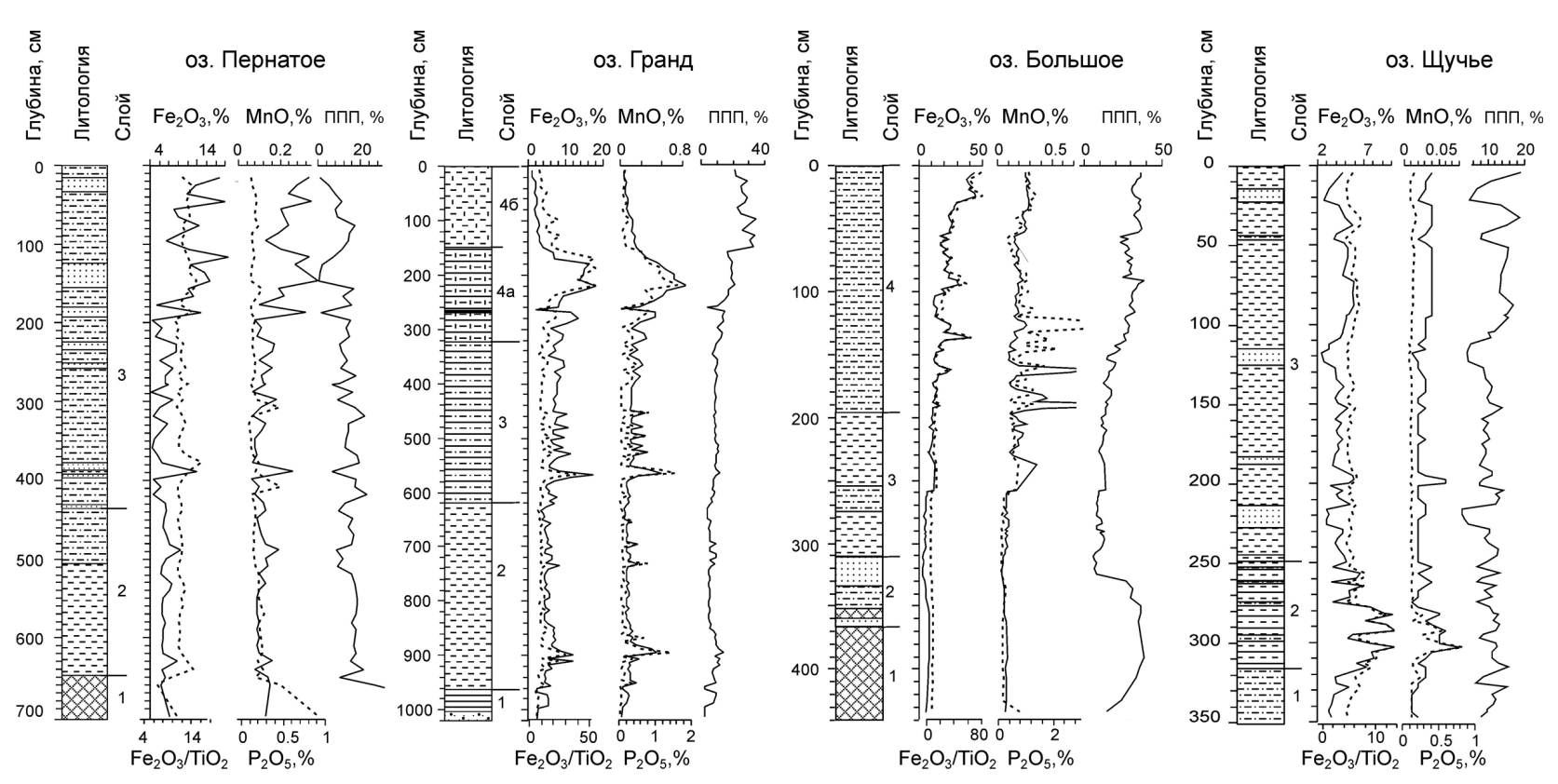

Pис. 4. Распределение $\mathrm{Fe}_{2} \mathrm{O}_{3}, \mathrm{MnO}, \mathrm{P}_{2} \mathrm{O}_{5}, \mathrm{Fe}_{2} \mathrm{O}_{3} / \mathrm{TiO}_{2}$, ППП в осадках оз. Пернатое, Гранд, Большое, Щучье (усл. обозн. см. на рис. 2)

Fig. 4. Distribution of $\mathrm{Fe}_{2} \mathrm{O}_{3}, \mathrm{MnO}, \mathrm{P}_{2} \mathrm{O}_{5}, \mathrm{Fe}_{2} \mathrm{O}_{3} / \mathrm{TiO}_{2}$, LOI by depth in the sediments of Lake Pernatoye, Lake Grand, Lake Bol'shoye, and Lake Shchuchye

зомарганцевых образованиях, сульфидах, фосфатах, диагностированных энергодисперсионной рентгеновской спектрометрией и термомагнитными исследованиями. Фосфор входит в вивианит, обильный в осадках озера и, согласно минералогическим данным, включает примесь марганца. Он также сорбируется оксидами железа, глинистыми минералами (Юдович, Кетрис, 2011; Gérard, 2016). Отношение Jrs/Js, как один из показателей доменной структуры, составляет в среднем 0.31 для обогащенных железом осадков, что предполагает однодоменное и суперпарамагнитное состояние магнитных частиц, образованных хемогенным (биогенным) путем.

Плейсточен-голоченовое оз. Большое. В осадках озера выделены 4 литологических слоя: слой 1 (гл. 439-365 см), торф с песком; слой 2 (гл. 365-310 см), алеврит, чередующийся с разнозернистыми песками; слой 3 (гл. 310-197 см), органогенный глинистый алеврит с прослоями песчаного алеврита, торфа, гальки, гравия; слой 4 (гл. 197-0 см), органогенный алеврит.

По содержанию железа осадки озера выделяются среди всех изученных в дальневосточном регионе. Концентрации этого элемента варьируют от 2.60 до 44.5\%, причем максимальные значения характеризуют не единичные образцы, а большой интервал, занимающий верхнюю часть разреза (см. рис. 4). Содержания $\mathrm{TiO}_{2}$ составляют $0.40-0.90 \%$. Отношение $\mathrm{Fe}_{2} \mathrm{O}_{3} / \mathrm{TiO}_{2}$ постепенно увеличивается вверх с интервала 180 см, достигая 82.31. Корреляция железа с титаном слабая обратная, $\mathrm{r}=-0.25$.

Ярко выраженные пики концентраций железа и марганца совпадают лишь в интервале глубин
161-164 см, хотя в целом по разрезу $\mathrm{Fe}_{2} \mathrm{O}_{3}$ положительно коррелирует с $\mathrm{MnO}(\mathrm{r}=0.39)$ и $\mathrm{P}_{2} \mathrm{O}_{5}(\mathrm{r}=$ 0.57). Коэффициент корреляции фосфора и марганца составляет 0.35 , что намного ниже, чем в осадках оз. Гранд. Скопления землистых форм вивианита голубого оттенка отмечены в верхней части разреза. Сильные вариации фосфора характерны для интервала 122-190 см, предположительно раннеголоценового возраста.

$\mathrm{Fe}_{2} \mathrm{O}_{3}$ позитивно коррелирует с магнитной восприимчивостью $(\mathrm{r}=0.70)$ и ее парамагнитной компонентой $(\mathrm{r}=0.71)$. Отношение Jrs/Js для голоценовых отложений составляет 0.29-0.49 (среднее 0.37), Bcr/Bc-1.75-2.15 (среднее 1.84), что указывает на однодоменное и суперпарамагнитное состояние магнитных частиц.

Высокие содержания железа в осадках оз. Большое связаны с условиями образования озера и литологическим составом озерного ложа. Озеро сформировано на болотных, озерноаллювиальных отложениях позднего плейстоцена, представленных торфяниками и кластическими осадками с прослоями органического материала. Разложение органики способствовало созданию восстановительных сред, растворению детритового и осажденного из растворов железа и миграции его вверх в придонные воды и осадки, где при других условиях редокса происходило выпадение твердых фаз железа. Предполагается, что основная масса железа осаждалась в виде $\mathrm{FeO}$, закисной формы железа. Кривые термомагнитного анализа из обогащенных железом осадков отличаются от кривых, типичных для ге-

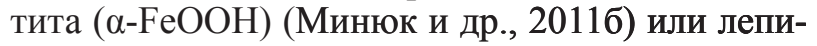
докрокита у-FeOOH (Минюк и др., 2013). 
Аномально высокие концентрации какоголибо породообразующего элемента приводят к уменьшению (разбавлению) содержаний других. Обычно в озерных осадках кремнезем влияет на содержания других оксидов. В голоценовых осадках оз. Большое недетритовое железо является главным разбавителем, что, например, отмечалось для осадков о3. Kutsasjärvi (Швеция) (Peinerud, 2000).

Позднеплейстоиен-голоценовое оз. Щучье. Особенности распределения $\mathrm{Fe}_{2} \mathrm{O}_{3}, \mathrm{TiO}_{2}, \mathrm{MnO}$ и $\mathrm{P}_{2} \mathrm{O}_{5}$ в осадках озера во многом схожие с таковыми о3. Гранд и Большое.

По содержанию $\mathrm{Fe}_{2} \mathrm{O}_{3}$ и $\mathrm{TiO}_{2}$ осадки ближе к отложениям о. Гранд: $\mathrm{Fe}_{2} \mathrm{O}_{3}=2.40-10.45 \%$ (среднее $4.93 \%$ ), $\mathrm{TiO}_{2}=0.52-0.95 \%$ (среднее $0.79 \%$ ). Отношение $\mathrm{Fe}_{2} \mathrm{O}_{3} / \mathrm{TiO}_{2}$ варьирует в пределах 4.30-13.57\% (среднее 6.18\%). Повышенные значения этого отношения (среднее $9.94 \%$ ) отмечены для отложений слоя 2 (гл. 250-315 см), представленного слоистыми алевритами с прослоями песчаных алевритов (Burnatny et al., 2019) (см. рис. 4). Железо позитивно коррелирует с $\mathrm{P}_{2} \mathrm{O}_{5}$ $(\mathrm{r}=0.67)$ и $\mathrm{MnO}(\mathrm{r}=0.63)$. Коэффициент корреляции $\mathrm{P}_{2} \mathrm{O}_{5}$ и $\mathrm{MnO}$ составляет 0.64. Основные пики $\mathrm{Fe}_{2} \mathrm{O}_{3}$ совпадают с минимумами отношения $\mathrm{Fe}_{2} \mathrm{O}_{3} / \mathrm{MnO}$, указывая на восстановительные среды осадконакопления. В отличие от осадков о3. Большое корреляция $\mathrm{Fe}_{2} \mathrm{O}_{3}$ и $\mathrm{TiO}_{2}$ положительная $(\mathrm{r}=0.41)$. Как и для осадков оз. Большое, наблюдается значимая позитивная корреляция $\mathrm{Fe}_{2} \mathrm{O}_{3}$ с магнитной восприимчивостью $(\mathrm{r}=0.88)$ и парамагнитной восприимчивостью $(\mathrm{r}=0.94)$. Отношение Jrs/Js составляет 0.24-0.62 (среднее $0.37)$, а Вcr/Вc - 1.38-2.21 (среднее 1.83), что указывает на однодоменное и суперпарамагнитное состояние магнитных частиц.

Минимальные содержания железа характерны для грубозернистых разностей осадков озера, в то время как в осадках Курильских озер наблюдается обратная зависимость. В отложениях с повышенными содержаниями железа (слой 2) диагностированы лепидокрокит и магнетит, предположительно, биогенного происхождения. Лепидокрокит имеет характерные кривые термомагнитного анализа с ростом MS при температуре $220^{\circ} \mathrm{C}$ и последующим спадом на температуре Кюри магнетита. Форма кристаллов лепидокрокита игольчатая, магнетит обнаружен в виде округлых стяжений, размером несколько десятков нанометров (Webster et al., 2012; Li et al., 2013; Burnatny et al., 2019).

ППП. Потери при прокаливании (до $550^{\circ} \mathrm{C}$ ) являются индикатором органического вещества в осадках, хотя при этих температурах происходит также потеря воды гидроксидами и глинистыми минералами, летучих компонентов солей (Heiri et al., 2001). При водном происхождении органики, что определяется по отношению органического углерода к азоту, ППП могут свидетельствовать о биопродуктивности бассейна. Рассмотрим значения этого параметра в осадках озер и с какими элементами и отношениями он связан.

Обычно в озерных осадках ППП всегда составляют несколько процентов, это так называемые фоновые значения.

В осадках оз. Малое значения ППП варьируют в пределах 4.98-25.28\% (среднее 17.2\%), причем для морских отложений ППП в среднем составляют $10.86 \%$, солоноватоводных - 19.07\%, пресноводных - $19.83 \%$ (см. рис. 4). ППП положительно коррелируют с $\mathrm{SiO}_{2 \text { bio }}(\mathrm{r}=0.92), \mathrm{SiO}_{2}(\mathrm{r}=$ $0.92), \mathrm{Ni}(\mathrm{r}=0.21), \mathrm{Al}_{2} \mathrm{O}_{3} /\left(\mathrm{CaO}+\mathrm{Na}_{2} \mathrm{O}\right)(\mathrm{r}=0.68)$. Максимальные значения ППП, как и биогенного кремнезема, характерны для пресноводных фаций и связаны с тонкими литологическими разностями.

Оз. Гранд. По ППП в осадках озера отчетливо выделяются два интервала (см. рис. 4). Для плейстоценовых отложений потери при прокаливании составляют 2.26-13.8 (среднее 7.56), для отложений МИС1 - 3.81-34.71 (среднее 20.87). Осадкам верхнего интервала свойственны и максимальные значения $\mathrm{SiO}_{2 \text { bio }}$ В целом по осадкам о3. Гранд наблюдается положительная корреляция ППП с $\mathrm{SiO}_{2 \text { bio }}(\mathrm{r}=0.77), \mathrm{SiO}_{2}(\mathrm{r}=0.67), \mathrm{P}_{2} \mathrm{O}_{5}$ $(\mathrm{r}=0.28), \mathrm{MnO}(\mathrm{r}=0.34), \mathrm{Ni}(\mathrm{r}=0.15), \mathrm{Fe}_{2} \mathrm{O}_{3} / \mathrm{TiO}$ $(\mathrm{r}=0.45), \mathrm{Al}_{2} \mathrm{O}_{3} /\left(\mathrm{CaO}+\mathrm{Na}_{2} \mathrm{O}\right)(\mathrm{r}=0.40), \mathrm{Al}_{2} \mathrm{O}_{3} /$ $\left(\mathrm{Na}_{2} \mathrm{O}+\mathrm{K}_{2} \mathrm{O}\right)^{2}(\mathrm{r}=0.90)$.

Общим для оз. Малое и Гранд является то, что ППП положительно коррелируют с детритовым и биогенным кремнеземом.

Оз. Щучье, оз. Чистое. В них доминирует детритовое осадконакопление. Грубые литологические разности обогащены терригенным кремнеземом, который позитивно коррелирует лишь с натрием, цирконием и стронцием (оз. Щучье) или натрием, кальцием, калием, цирконием и стронцием (оз. Чистое). Средние содержания ППП для осадков оз. Щучье и Чистое составляют соответственно 10.6 и $10.0 \%$.

Для осадков оз. Щучье наблюдается положительная корреляция ППП с $\mathrm{Al}_{2} \mathrm{O}_{3} /\left(\mathrm{CaO}+\mathrm{Na}_{2} \mathrm{O}\right)$ $(\mathrm{r}=0.69), \mathrm{CaO}(\mathrm{r}=0.69), \mathrm{Al}_{2} \mathrm{O}_{3}(\mathrm{r}=0.68), \mathrm{MgO}(\mathrm{r}=$ $0.66), \mathrm{K}_{2} \mathrm{O}(\mathrm{r}=0.58), \mathrm{Ni}(\mathrm{r}=0.56), \mathrm{TiO}_{2}(\mathrm{r}=0.54)$, $\mathrm{Fe}_{2} \mathrm{O}_{3}(\mathrm{r}=0.49), \mathrm{Cr}(\mathrm{r}=0.49), \mathrm{Fe}_{2} \mathrm{O}_{3} / \mathrm{TiO}_{2}(\mathrm{r}=0.36)$, $\mathrm{MnO}(\mathrm{r}=0.27), \mathrm{P}_{2} \mathrm{O}_{5}(\mathrm{r}=0.18)$.

В осадках оз. Чистое ППП значимо позитивно коррелируют с $\mathrm{Fe}_{2} \mathrm{O}_{3}(\mathrm{r}=0.82), \mathrm{Al}_{2} \mathrm{O}_{3}(\mathrm{r}=0.73)$, $\mathrm{TiO}_{2}(\mathrm{r}=0.72), \mathrm{MnO}(\mathrm{r}=0.72), \mathrm{Al}_{2} \mathrm{O}_{3} /\left(\mathrm{CaO}+\mathrm{Na}_{2} \mathrm{O}\right)$ $(\mathrm{r}=0.63), \mathrm{Fe}_{2} \mathrm{O}_{3} / \mathrm{TiO}(\mathrm{r}=0.58), \mathrm{MgO}(\mathrm{r}=0.37)$, $\mathrm{P}_{2} \mathrm{O}_{5}(\mathrm{r}=0.19)$. Перечисленные оксиды и элементы имеют повышенные содержания в тонких литологических разностях обоих озер.

ППП в осадках оз. Большое варьируют в пределах 5.7-38.6\% (см. рис. 4). Максимальные значения характерны для болотных фаций позднего плейстоцена, представленных торфяниками, а также для голоценовых озерных осадков. В отличие от ППП осадков предыдущих озер этот пара- 
метр позитивно коррелирует лишь с $\mathrm{Al} /(\mathrm{Ca}+\mathrm{Na})$ $(\mathrm{r}=0.77), \mathrm{Fe}_{2} \mathrm{O}_{3} / \mathrm{TiO}(\mathrm{r}=0.66), \mathrm{Ni}(\mathrm{r}=0.65), \mathrm{P}_{2} \mathrm{O}_{5}$ $(\mathrm{r}=0.38), \mathrm{Cr}(\mathrm{r}=0.32)$ и $\mathrm{MnO}(\mathrm{r}=0.13)$.

Таким образом, во всех изученных озерах независимо от географического положения, возраста и генезиса повышенные значения потерь при прокаливании свойственны тонкозернистым осадкам. Это может косвенно указывать на водное происхождение органического вещества. Прямая корреляция ППП с размером зерен осадков отмечена во многих озерах. Высокие значения ППП в грубозернистых осадках могут свидетельствовать об аллохтонном генезисе органики (Munroe, 2012). В целом органическое вещество в осадках является своеобразным разбавителем, влияющим на магнитные свойства, что необходимо учитывать при интерпретации петрофизических данных.

\section{ЗАКЛЮЧЕНИЕ}

Химический анализ использован для определения генезиса осадков, характеристики среды и условий седиментации, постседиментационных изменений. По многим геохимическим параметрам прибрежные озера отличаются от континентальных, хотя отмечаются общие закономерности.

Индикаторы продуктивности озер, такие как биогенный кремнезем, органическое вещество, определены по отношению $\mathrm{SiO}_{2} / \mathrm{TiO}_{2}$, анализу распределения общего кремнезема, ППП. Биогенное накопление кремнезема характерно для всех исследованных озер Курильского архипелага, а также оз. Гранд с максимальной интенсивностью в позднем голоцене. В осадках оз. Чистое, Щучье, Большое, в плейстоценовых отложениях оз. Гранд доминирует в основном детритовый кремнезем.

Органическое вещество осадков имеет преимущественно автохтонное происхождение. Обогащение органическим веществом характерно для тонкозернистых осадков. В осадках оз. Гранд и Большое, охватывающих несколько изотопных стадий, постепенное увеличение содержания органики отмечено в течение последней стадии (МИС1), в осадках оз. Щучье - для второй половины голоцена. При доминирующей роли биогенной седиментации низкие значения ППП указывают на поступление в бассейн кластического материала.

Параметр $\mathrm{Al}_{2} \mathrm{O}_{3} /\left(\mathrm{Na}_{2} \mathrm{O}+\mathrm{CaO}\right)$ может применяться как индикатор размерности зерен с большими значениями для тонкозернистых осадков.

Отношение $\mathrm{Fe}_{2} \mathrm{O}_{3} / \mathrm{TiO}_{2}$ в сравнении с $\mathrm{Fe}_{2} \mathrm{O}_{3}$ является показателем детритового и хемогенного (биогенное) происхождения железа. Железо и марганец в осадках озер Курильского архипелага связаны преимущественно с детритовыми минералами, а озер континентальной части СевероВостока - с аутигенными.
Тренд выветривания коренных пород, грубозернистых и тонкозернистых озерных осадков указывает на локальные источники сноса. Вулканические пеплы химически изменены меньше по сравнению с вмещающими осадками.

Работа выполнена при финансовой поддержке РФФИ (грант 19-05-00477).

\section{ЛИТЕРАТУРА}

Даувальтер В. В., Кашулин Н. А. Геоэкология озер Мурманской области : монография: в 3-х ч. Ч. 3. Донные отложения водоемов. Мурманск : Изд-во МГТУ, 2014. $214 \mathrm{c}$.

Левитан М. А., Сыромятников К. В., Кузьмина Т. Г. Некоторые литолого-геохимические особенности современной четвертичной седиментации в Северном Ледовитом океане // Геохимия. 2012. № 7. С. 627-643.

Ложкин А. В., Андерсон П. М., Браун Т. А., Важенина Л. Н., Матросова Т. В., Минюк П. С., Пахомов А. Ю., Соломаткина Т. Б. Новая летопись изменения климата и растительности Северного Приохотья в течение изотопных стадий 1-4 // Вестник СВНЦ ДВО PAH. 2010. № 1. C. 63-70.

Мигдисов А. А. О соотношении титана и алюминия в осадочных породах // Геохимия. 1960. № 2. C. $149-163$.

Минюк П. С., Борходоев В. Я., Горячев Н. А. Геохимические характеристики осадков оз. Эльгыгытгын (Чукотка) как показатели климатических изменений за последние 350 тыс. лет // ДАН. 2011а. Т. 436, № 2. C. $239-242$.

Минюк П. С., Борходоев В. Я. Геохимия осадков озера Гранд, Северо-Восток России // Геохимия. 2016. № 9. С. $841-851$.

Минюк П. С., Ложкин А. В., Андерсон П. М., Соломаткина Т. Б., Пахомов А. Ю., Борходоев В. Я. Комплексные исследования осадков озера Энгтери, Северо-Восток России // Вестник СВНЦ ДВО РАН. 2007. № 4. C. $2-13$.

Минюк П. С., Новачек Н. Р., Глушикова О. Ю., Смирнов В. Н., Бригхем-Гретте Дж., Меллес М., Черепанова М. В., Ложкин А. В., Андерсон П., Матросова Т. В., Хуббертен Г., Белая Б. В., Борходоев В.Я., Форман С.Л., Асикайнен С., Лейер П., Нолан М., Прокеин П., Листон Г., Нантзингер Р., Шарптон В., Ниссен Ф. Палеоклиматические данные озера Эльгыгытгын, Северо-Восток России (комплексные исследования) // Процессы постседиментационного намагничивания и характер изменения магнитного поля и климата Земли в прошлом. Магадан : СВКНИИ ДВО РАН, 2003. С. 91-135.

Минюк П. С., Субботникова Т. В., Андерсон П. М., Ложкин $A$. В. Петромагнитные свойства осадков озеpa Пернатое (остров Парамушир, Курильская гряда) как показатели изменений условий осадконакопления // Физика Земли. 2013. № 1. С. 1-10.

Минюк П. С., Субботникова Т. В., Пляшкевич А. А. Термокаппаметрия гетита и гематита // Там же. 20116. №. 9. C. $18-30$.

Ронов А. Б., Мигдисов А. А. Основные черты геохимии элементов-гидролизатов в процессе выветривания и осадконакопления // Геохимия. 1965. № 2. C. $131-158$.

Страховенко В. Д., Солотчина Э. П., Восель Ю. С., Солотчин П. А. Геохимические факторы аутигенно- 
го минералообразования в донных отложениях Тажеранских озер (Прибайкалье) // Геология и геофизика. 2015. T. 56, № 10. С. 1825-1841.

Черепанова М. В., Авраменко А. С., Андерсон П. М., Ложкин А. В., Минюк П. С., Пушкарь В. С. Диатомовые водоросли оз. Эликчан (Северное Приохотье) и их значение для реконструкции развития экосистемы озера за последние 70 тыс. лет // Вестник СВНЦ ДВО РАН. 2013. № 1. С. 3-15.

Юдович Я. Э., Кетрис М. П. Геохимические индикаторы литогенеза (литологическая геохимия). Сыктывкар : Геопринт, 2011. 742 с.

Юдович Я. Э., Кетрис М. П. Геохимия марганца. Сыктывкар : ИГ Коми НЦ УрО РАН, 2014. 540 с.

Adamson K., Lane T., Carney M., Bishop T., Delaney $C$. High-resolution proglacial lake records of pre-Little Ice Age glacier advance, northeast Greenland // Boreas. 2019. Vol. 48. P. 535-550. 76tps://doi.org/10.1111/bor

Anderson P., Minyuk P., Lozhkin A., Cherepanova M., Borkhodoev V., Finney B. A multiproxy record of Holocene environmental changes from the northern Kuril Islands (Russian Far East) // Journal of Paleolimnology. 2015. Vol. 54. P. 379-393.

Archer C., Noble P., Rosen M. R., Sagnotti L., Florindo F., Mensing S., Piovesan G., Michetti A. M. Lakes as paleoseismic records in a seismically-active, low-relief area (Rieti Basin, Central Italy) // Quaternary Science Reviews. 2019. Vol. 211. P. 186-207.

Avşar $U$. Sedimentary geochemical evidence of historical tsunamis in the Eastern Mediterranean from Ölüdeniz Lagoon, SW Turkey // Journal of Paleolimnology. 2019. Vol. 61. P. 373-385.

Bellwald B., Hjelstuen B. O., Sejrup H. P., Stokowy T., Kuvas $J$. Holocene mass movements in west and mid-Norwegian fjords and lakes // Marine Geology. 2019. Vol. 407. P. 192-212.

Bertrand S., Charlet F., Charlier B., Renson V., Fagel $N$. Climate variability of Southern Chile since the Last Glacial Maximum: a continuous sedimentological record from Lago Puyehue (40 $\mathrm{S}) / /$ Journal of Paleolimnology. 2008. Vol. 39. P. 179-195.

Bessa A. Z. E., Ngueutchoua G., Ndjigui P.-D. Mineralogy and geochemistry of sediments from Simbock Lake, Yaoundé area ( Southern Cameroon): provenance and environmental implications // Arabian Journal of Geosciences. 2018. Vol. 11. P. 710. https://doi.org/10.1007/ s12517-018-4061-x

Bovle J. F. Inorganic geochemical methods in paleolimnology. In Tracking environmental change using lake sediments. Vol. 2. Physical and geochemical methods / Eds. M. W. Last, J. P. Smol). Kluwer Academic Publishers, 2002. P. 83-142.

Brown E. Lake Malawi's response to "megadrought" terminations: sedimentary records of flooding, weathering and erosion // Palaeogeography, Palaeoclimatology, Palaeoecology. 2011. Vol. 303. P. 120-125.

Brunscho C., Haberzettl T., Behling H. High-resolution studies on vegetation succession, hydrological variations, anthropogenic impact and genesis of a subrecent lake in southern Ecuador // Veget. Hist. Archaeobot. 2010. Vol. 19. P. 191-206.

Buggle B., Glaser B., Hambach U., Gerasimenko N., Marković S. An evaluation of geochemical weathering indices in loess- paleosol studies // Quaternary International. 2010. doi:10.1016/j.quaint.2010.07.019.
Bulkan Ö., Yalçın M. N., Wilkes H. Geochemistry of Marmara Lake sediments - implications for Holocene environmental changes in Western Turkey // Quaternary International. 2018. Vol. 486. P. 199-214.

Burnatny S. S., Naumov A. N., Korzun Yu. A. A 13.000Yr record of environmental change from Tschuchye Lake in Northeast Yakutia // Recent advances in rock magnetism, environmental magnetism and paleomagnetism / International conference on geomagnetism, paleomagnetism and rock magnetism (Kazan, Russia) / Eds. D. Nurgaliev, V. Shcherbakov, A. Kosterov, S. Spassov. Springer Geophysics. 2019. P. 133-150.

Chagué-Goff C., Szczuciński W., Shinozaki T. Applications of geochemistry in tsunami research: A review // Earth-Science Reviews. 2017. Vol. 165. P. 203-244.

Chen X.-Y., McLean D., Blockley S. P. E., Tarasov P. E., Xu Y.-G., Menzies M. A. Developing a Holocene tephrostratigraphy for Northern Japan using the sedimentary record from Lake Kushu, Rebun Island // Quaternary Science Reviews. 2019. Vol. 215. P. 272-292.

Cvetkoska A., Levkov Z., Reed J. M., Wagner B. Late Glacial to Holocene climate change and human impact in the Mediterranean: The last ca. 17 ka diatom record of Lake Prespa (Macedonia/Albania/Greece) // Palaeogeography, Palaeoclimatology, Palaeoecology. 2014. Vol. 406. P. 22-32.

Davison $W$. Iron and manganese in lakes // Earth Sci. Rev. 1993. Vol. 34. P. 119-163.

De Jayawardena U. S., Izawa E. A new Chemical Index of Weathering for metamorphic silicate rocks in tropical regions: a study from Sri Lanka // Engineering Geology. 1994. Vol. 36. P. 303-310.

Fedo C. M., Nesbitt H. W., Young G. M. Unraveling the effects of potassium metasomatism in sedimentary rocks and paleosols, with implications for paleoweathering conditions and provenance // Geology. 1995. Vol. 23. P. 921- 924.

Fey M., Korr C., Maidana N. I., Carrevedo M. L., Corbella H., Dietrich S., Haberzettl T., Kuhn G., Lücke A., Mayr C., Ohlendorf C., Paez M. M., Quintana F. A., Schäbitz F., Zolitschka B. Palaeoenvironmental changes during the last 1600 years inferred from the sediment record of a cirque lake in Southern Patagonia (Laguna Las Vizcachas, Argentina) // Palaeogeography, Palaeoclimatology, Palaeoecology. 2009. Vol. 281. P. 363-375.

Fralick P. W., Kronberg B. I. Geochemical discrimination of elastic sedimentary rock sources // Sedimentary Geology. 1997. Vol. 113. P. 111-124.

Francke A., Wennrich V., Sauerbrey M., Juschus O., Melles M., Brigham-Grette J. Multivariate statistic and time series analyses of grain-size data in quaternary sediments of Lake El'gygytgyn, NE Russia // Climate of the Past. 2013. Vol. 9. P. 2459-2470. DOI: 10.5194/cp-9-2459-2013

Frugone-Álvarez M., Latorre C., Giralt S., PolancoMartínez J., Bernárdez P., Oliva-Urcia B., Maldonado A., Carrevedo M. L., Moreno A., Delgado Huertas A., Prego R., Barreiro-Lostres F., Valero-Garcés, B. A 7000-year high resolution lake sediment record from coastal Central Chile (Lago Vichuquén, $34^{\circ} \mathrm{S}$ ): Implications for past sea level and environmental variability // J. Quat. Sci. 2017. Vol. 12. P. 830-844.

Gérard F. Clay minerals, iron/aluminum oxides, and their contribution to phosphate sorption in soils - A myth revisited // Geoderma. 2016. Vol. 262. P. 213-226.

Harnois L. The CIW index: A new chemical index of weathering // Sedimentary Geology. 1988. Vol. 55. P. 319-322. 
Heiri O., Lotter A. F., Lemcke G. Loss on ignition as a method for estimating organic and carbonate content in sediments: reproducibility and comparability of results // Journal of Paleolimnology. 2001. Vol. 25. P. 101-110.

Kronberg B. I., Nesbitt H. W. Quantification of weathering, soil geochemistry and soil fertility // Journal of Soil Science. 1981. Vol. 32. P. 453-459.

Leinen $M$. A normative calculation technique for determining opal in deep-sea sediments // Geochimica et Cosmochimica Acta. 1977. Vol. 41. P. 671-676.

Li J., Benzerara K., Bernard S., Beyssac O. The link between biomineralization and fossilization of bacteria: Insights from field and experimental studies // Chemical Geology. 2013. Vol. 359. P. 49-69.

Lozhkin A., Minyuk P., Cherepanova M., Anderson P., Finney $B$. Holocene environments of central Iturup Island, southern Kuril archipelago, Russian Far East // Quaternary Research. 2017. Vol. 88 (1). P. 23-38.

Mackereth F. J. H. Some chemical observations on post-glacial lake sediments // Philos. T. Roy. Soc. B. 1966. Vol. 256. P. 165-213.

Melles M., Brigham-Grette J., Minyuk P. S., Nowaczyk N. R., Wennrich V., DeConto R. M., Anderson P. M., Andreev A. A., Coletti A., Cook T. L., Haltia-Hovi E., Kukkonen M., Lozhkin A. V., Rosén P., Tarasov P., Vogel H., Wagner B. 2.8 million years of Arctic climate change from Lake El'gygytgyn, NE Russia // Science. 2012. Vol. 337. P. 315-320.

Minyuk P. S., Borkhodoev V. Ya., Goryachev N. A. Geochemical characteristics of sediments from Lake El'gygytgyn, Chukotka Peninsula, as indicators of climatic variations for the past $350 \mathrm{ka} / /$ Doklady Earth Sciences. 2011. Vol. 436. Part 1. P. 94-97.

Minyuk P. S., Borkhodoev V. Y., Wennrich V. Inorganic geochemistry data from Lake El'gygytgyn sediments: marine isotope stages 6-11// Climate of the Past. 2014. Vol. 10. P. 467-485.

Minyuk P. S., Brigham-Grette J., Melles M., Borkhodoev V. Ya., Glushkova O. Yu. Inorganic geochemistry of El'gygytgyn Lake sediments, Northeastern Russia, as an indicator of paleoclimatic change for the last $250 \mathrm{kyr} / /$ Journal of Paleolimnology. 2007. Vol. 37, 1. P. 123-133.

Moreira S., Costa P. J. M., Andrade C., Lira C. P., Freitas M. C., Oliveira M. A., Reichart G.-J. High resolution geochemical and grain-size analysis of the AD 1755 tsunami deposit: Insights into the inland extent and inundation phases // Marine Geology. 2017. Vol. 390. P. 94-105.

Munroe J. S. Lacustrine records of post-glacial environmental change from the Nulhegan Basin, Vermont, USA // Journal of Quaternary Science. 2012. Vol. 27 (6). P. 639-648.

Nesbitt H. W., Young G. M. Early Proterozoic climates and plate motions inferred from major element chemistry of lutites // Nature. 1982. Vol. 299. P. 715-717.

Nesbitt H. W., Young G. M., McLennan S. M., Keays $R$. $R$. Effects of chemical weathering and sorting on the petrogenesis of siliciclastic sediments, with implications for provenance studies // The Journal of Geology. 1996. Vol. 104. P. 525-542.

Nesbitt H. W., Young G. M. Prediction of some weathering trends of plutonic and volcanic rocks based on thermodynamic and kinetic considerations // Geochim. Cosmochim. Acta. 1984. Vol. 48. P. 1523-1534.

Поступила в редакичюю 23.12.2019 2.

Поступила после доработки 16.01.2020 2.
Peinerud E. K. Interpretation of Si concentrations in lake sediments: three case studies // Environmental Geology. 2000. Vol. 40 (1-2). P. 64-72.

Rapuc W., Sabatier P., Arnaud F., Palumbo A., Develle A.-L., Reyss J.-L., Augustin L., Régnier E., Piccin A., Chapron E., Dumoulin J.-P., von Grafenstein U. Holocenelong record of flood frequency in the Southern Alps (Lake Iseo, Italy) under human and climate forcing // Global and Planetary Change. 2019. Vol. 175. P. 160-172.

Reynolds R. L., Rosenbaum J. G., Rapp J., Kerwin M. W., Bradbury J. P., Colman S., Adam D. Record of late Pleistocene glaciation and deglaciation in the southern Cascade Range. I. Petrological evidence from lacustrine sediment in Upper Klamath Lake, southern Oregon // Journal of Paleolimnology. 2004. Vol. 31. P. 217-233.

Ruxton B. P. Measures of degree of chemical weathering of rocks // J. Geol. Vol. 1968. Vol. 76. P. 518-527.

Sauerbrey M. A., Juschus O., Gebhardt A. C., Wennrich $V$., Nowaczyk N. R., Melles M. Mass movement deposits in the 3.6Ma sediment record of Lake El'gygytgyn, Far East Russian Arctic // Climate of the Past. 2013. Vol. 9. P. 1949-1967.

Schmidt M., Leipe C., Becker F., Goslar T., Hoelzmann P., Mingram J., Muller S., Tjallingii R., Wagner M., Tarasov P. E. A multi-proxy palaeolimnological record of the last 16.600 years from coastal Lake Kushu in northern Japan // Palaeogeography, Palaeoclimatology, Palaeoecology. 2019. Vol. 514. P. 613-626.

Speranza F. C., Giralt S., Lupo L. C., Kulemeyer J. J., Pereira E. de los Á., López B. C. Paleoenvironmental reconstruction of the semi-arid Chaco region of Argentina based on multiproxy lake records over the last six hundred years // Ibid. 2019. Vol. 524. P. 85-100.

Sun W., Liu E., Zhang E., Shen J. Geochemistry of the holocene sediments of Lake Chenghai, SW China, and its implications for paleoenvironmental reconstruction // Quaternary International. 2019. Vol. 523. P. 80-88.

Tanaka K., Akagawa F., Yamamoto K., Tani Y., Kawabe I., Kawai T. Rare earth element geochemistry of Lake Baikal sediment: its implication for geochemical response to climate change during the Last Glacial/Interglacial transition // Quaternary Sci. Rev. 2007. Vol. 26. 1362-1368.

Von Eynatten H., Tolosana-Delgado R., Karius V. Sediment generation in modern glacial setting: Grain-size and source-rock control on sediment composition // Sediment. Geol. 2012. Vol. 280. P. 80-92.

Webster N. A. S., Loan M. J., Madsen I. C., Knott R. B., Brodie G. M., Kimpton J. A. An in situ synchrotron X-ray diffraction investigation of lepidocrocite and ferrihydriteseeded $\mathrm{Al}(\mathrm{OH})_{3}$ crystallisation from supersaturated sodium aluminate liquor // Journal of Crystal Growth. 2012. Vol. 340. P. 112-117.

Wei $W$., Algeo T. J. Elemental proxies for paleosalinity analysis of ancient shales and mudrocks // Geochimica et Cosmochimica Acta. 2019. https://doi.org/10.1016/j. gca.2019.06.034

Wright H. E. Jr., Mann D. H., Glaser P. H. Piston corers for peat and lake sediments // Ecology. 1984. Vol. 65. P. 657-659.

Zhong W., Pen Z., Xue J., Ouyang J., Tang X., Cao J. Geochemistry of sediments from Barkol Lake in the westerly influenced northeast Xinjiang: Implications for catchment weathering intensity during the Holocene // J. Asian Earth Sci. 2012. Vol. 50. P. 7-13. 


\title{
GEOCHEMICAL STUDIES OF LAKE SEDIMENTOGENESIS IN THE FAR EAST OF RUSSIA
}

\author{
P. S. Minyuk, V. Ya. Borkhodoev, S. S. Burnatny
}

\author{
North-East Interdisciplinary Scientific Research Institute n. a. N. A. Shilo, FEB RAS, Magadan
}

Lakes of the Kuril Islands (Maloye, Tokatan, Pernatoye), Magadan Oblast (Grand, Chistoye, Bol'shoye), Yakutia ( Shchuchye), Chukotka (El'gygytgyn) were studied. Geochemical data were used to determine the origin of sediments as well as environmental, sedimentation, and post-sedimentation changes. Biogenic accumulation of silica is typical for the sediments of Lake Maloye and Lake Pernatoye, with maximum intensity in the second half of the Holocene. Detrital silica dominated in sediments of Lake Chistoye, Lake Shchuchye, and Lake Bol'shoye. The loss on ignition is used to estimate the relative amount of the organic material and show the maximal content in the Holocene sediments from Lake Maloye, Lake Bol'shoye, and Lake Grand. With biogenic sedimentation dominating, low values of the loss on ignition indicate the influx of the clastic material into the basin. The $\mathrm{Al}_{2} \mathrm{O}_{3} /\left(\mathrm{Na}_{2} \mathrm{O}+\mathrm{CaO}\right)$ parameter indicates the grain size with large values for fine-grained sediments. The $\mathrm{Fe}_{2} \mathrm{O}_{3} / \mathrm{TiO}_{2}$ ratio, in comparison with $\mathrm{Fe}_{2} \mathrm{O}_{3}$, serves as an indicator of detrital and chemogenic (biogenic) origin of iron. In the lacustrine sediments from the Kurils, manganese is associated with detrital minerals, while for sediments from continental lakes in the North-East, with authigenic. The trend for the weathering of bedrock, coarse-grained and fine-grained lake sediments indicates the local catch ments.

Keywords: lacustrine sedimentation, geochemistry, Pleistocene, Holocene, Far East.

\section{REFERENCES}

Adamson, K.; Lane, T.; Carney, M.; Bishop, T.; Delaney, C., 2019, High-Resolution Proglacial Lake Records of Pre-Little Ice Age Glacier Advance, Northeast Greenland, Boreas, 48, 535-550, 76tps://doi.org/10.1111/bor

Anderson, P.; Minyuk, P.; Lozhkin, A.; Cherepanova, M.; Borkhodoev, V.; Finney, B., 2015, A Multiproxy Record of Holocene Environmental Changes from the Northern Kuril Islands (Russian Far East), Journal of Paleolimnology, 54, 379-393.

Archer, C.; Noble, P.; Rosen, M. R.; Sagnotti, L.; Florindo, F.; Mensing, S.; Piovesan, G.; Michetti, A. M., 2019, Lakes as Paleoseismic Records in a SeismicallyActive, Low-Relief Area (Rieti Basin, Central Italy), Quaternary Science Reviews, 211, 186-207.

Avşar, U., 2019, Sedimentary Geochemical Evidence of Historical Tsunamis in the Eastern Mediterranean from Ölüdeniz Lagoon, SW Turkey, Journal of Paleolimnology, 61, 373-385.

Bellwald, B.; Hjelstuen, B. O.; Sejrup, H. P.; Stokowy, T.; Kuvas, J., 2019, Holocene Mass Movements in West and Mid-Norwegian Fjords and Lakes, Marine Geology, 407, 192-212.

Bertrand, S.; Charlet, F.; Charlier, B.; Renson V.; Fagel, N., 2008, Climate Variability of Southern Chile Since the Last Glacial Maximum: a Continuouss Sedimentological Record from Lago Puyehue $\left(40^{\circ} \mathrm{S}\right)$, Journal of Paleolimnology, 39, 179-195.

Bessa, A. Z. E.; Ngueutchoua, G.; Ndjigui P.-D., 2018, Mineralogy and Geochemistry of Sediments from Simbock Lake, Yaoundé Area (Southern Cameroon): Provenance and Environmental Implications, Arabian Journal of Geosciences, 11, 710, https://doi.org/10.1007/s12517018-4061-x

Bovle, J. F., 2002, Inorganic Geochemical Methods in Paleolimnology, Tracking Environmental Change Using Lake Sediments. Vol. 2. Physical and Geochemical
Methods, Eds. Last M. W., Smol J. P., Kluwer Academic Publishers, 83-142.

Brown, E., 2011, Lake Malawi’s Response to "Megadrought" Terminations: Sedimentary Records of Flooding, Weathering and Erosion, Palaeogeography, Palaeoclimatology, Palaeoecology, 303, 120-125.

Brunscho, C.; Haberzettl, T.; Behling, H., 2010, Highresolution Studies on Vegetation Succession, Hydrological Variations, Anthropogenic Impact and Genesis of a Subrecent Lake in Southern Ecuador, Veget. Hist. Archaeobot., 19, 191-206.

Buggle, B.; Glaser, B.; Hambach, U.; Gerasimenko, N.; Marković, S., 2010, An Evaluation of Geochemical Weathering Indices in Loesse Paleosol Studies, Quaternary International, DOI: 10.1016/j.quaint.2010.07.019

Bulkan, Ö.; Yalçın, M. N.; Wilkes, H., 2018, Geochemistry of Marmara Lake Sediments - Implications for Holocene Environmental Changes in Western Turkey, Ibid., 486, 199-214.

Burnatny, S. S.; Naumov, A. N.; Korzun, Yu. A., 2019, A 13.000-Yr Record of Environmental Change from Tschuchye Lake in Northeast Yakutia, Recent Advances in Rock Magnetism, Environmental Magnetism and Paleomagnetism, International Conference on Geomagnetism, Paleomagnetism and Rock Magnetism (Kazan, Russia), Eds. D. Nurgaliev, V. Shcherbakov, A. Kosterov, S. Spassov, Springer Geophysics, 133150 .

Chagué-Goff, C.; Szczuciński, W.; Shinozaki, T., 2017, Applications of Geochemistry in Tsunami Research: A Review, Earth-Science Reviews, 165, 203-244.

Chen, X.-Y.; McLean, D.; Blockley, S. P. E.; Tarasov, P. E.; Xu, Y.-G.; Menzies, M. A., 2019, Developing a Holocene Tephrostratigraphy for Northern Japan Using the Sedimentary Record from Lake Kushu, Rebun Island, Quaternary Science Reviews, 215, 272-292. 
Cherepanova, M. V.; Avramenko, A. S.; Anderson, P. M.; Lozhkin, A. V.; Minyuk, P. S.; Pushkar, V. S., 2013, Diatoms from the Elikchan Lake (Northern Priokhotje) and Their Value for Reconstruction of Lake Evolution Within the Last 70 Thousand Years, Vestnik NESC FEB RAS, 1, 3-15 [In Russian].

Cvetkoska, A.; Levkov, Z.; Reed, J. M.; Wagner, B., 2014, Late Glacial to Holocene Climate Change and Human Impact in the Mediterranean: The Last ca. 17 ka Diatom Record of Lake Prespa (Macedonia/ Albania/Greece), Palaeogeography, Palaeoclimatology, Palaeoecology, 406, 22-32.

Dauvalter, V. A.; Kashulin, N. A., 2014, Geoecology of the Lakes of the Murmansk Region, Murmansk, MGTU [In Russian].

Davison, W., 1994, Iron and Manganese in Lakes, Earth Sci. Rev., 34, 119-163.

De Jayawardena, U. S.; Izawa, E., 1994, A New Chemical Index of Weathering for Metamorphic Silicate Rocks in Tropical Regions: a Study from Sri Lanka, Engineering Geology, 36, 303-310.

Fedo, C. M.; Nesbitt, H. W.; Young, G. M., 1995, Unraveling the Effects of Potassium Metasomatism in Sedimentary Rocks and Paleosols, with Implications for Paleoweathering Conditions and Provenance, Geology, 23, 921- 924.

Fey, M.; Korr, C.; Maidana, N. I.; Carrevedo, M. L.; Corbella,H.;Dietrich, S.;Haberzettl, T.; Kuhn, G.;Lücke,A.; Mayr, C.; Ohlendorf, C.; Paez, M. M.; Quintana, F. A., Schäbitz, F.; Zolitschka, B., 2009, Palaeoenvironmental Changes during the Last 1600 Years Inferred from the Sediment Record of a Cirque Lake in Southern Patagonia (Laguna Las Vizcachas, Argentina), Palaeogeography, Palaeoclimatology, Palaeoecology, 281, 363-375.

Fralick, P. W., Kronberg, B. I., 1997, Geochemical Discrimination of Elastic Sedimentary Rock Sources, Sedimentary Geology, 113, 111-124.

Francke, A.; Wennrich, V.; Sauerbrey, M.; Juschus, O.; Melles, M.; Brigham-Grette, J., 2013, Multivariate Statistic and Time Series Analyses of Grain-Size Data in Quaternary Sediments of Lake El'gygytgyn, NE Russia, Climate of the Past, 9, 2459-2470, doi:10.5194/cp-92459-2013

Frugone-Álvarez, M.; Latorre, C.; Giralt, S.; PolancoMartínez, J.; Bernárdez, P.; Oliva-Urcia, B.; Maldonado, A.; Carrevedo, M. L.; Moreno, A.; Delgado Huertas, A.; Prego, R.; Barreiro-Lostres, F.; Valero-Garcés, B., 2017, A 7000-year High Resolution Lake Sediment Record from Coastal Central Chile (Lago Vichuquén, $34^{\circ} \mathrm{S}$ ): Implications for Past Sea Level and Environmental Variability, J. Quat. Sci., 12, 830-844.

Gérard, F., 2016, Clay Minerals, Iron/Aluminum Oxides, and Their Contribution to Phosphate Sorption in Soils - A Myth Revisited, Geoderma, 262, 213-226.

Harnois, L., 1988, The CIW Index: A New Chemical Index of Weathering, Sedimentary Geology, 55, 319322.

Heiri, O.; Lotter, A. F.; Lemcke G., 2001, Loss on Ignition as a Method for Estimating Organic and Carbonate Content in Sediments: Reproducibility and Comparability of Results, Journal of Paleolimnology, 25, 101-110.

Kronberg, B. I.; Nesbitt, H. W., 1981, Quantification of Weathering, Soil Geochemistry and Soil Fertility, Journal of Soil Science, 32, 453-459.
Leinen, M., 1977, A Normative Calculation Technique for Determining Opal in Deep-Sea Sediments, Geochemica et Cosmochimica Acta, 41, 671-676.

Levitan, M. A.; Syromyatnikov, K. V.; Kuz'mina, T. G., 2012, Lithological and Geochemical Characteristics of Quaternary Sedimentation in the Arctic Ocean, Geochemistry International, 50 (7), 559-573.

Li, J.; Benzerara, K.; Bernard, S.; Beyssac, O., 2013, The Link Between Biomineralization and Fossilization of Bacteria: Insights from Field and Experimental Studies, Chemical Geology, 359, 49-69.

Lozhkin,A.;Minyuk, P.; Cherepanova,M.; Anderson,P.; Finney, B., 2017, Holocene Environments of Central Iturup Island, Southern Kuril Archipelago, Russian Far East, Quaternary Research, 88 (1), 23-38.

Lozhkin, A. V.; Anderson, P. M.; Brown, T. A.; Vazhenina, L. N.; Matrosova, T. V.; Minyuk, P. S.; Pakhomov, A. Yu.; Solomatkina, T. B., 2010, New Records of Changes in Climates and Plants Through 4-1 Isotopic Stages over the Northern Priokhotje Territory, Vestnik NESC FEB RAS, 1, 63-70 [In Russian].

Mackereth, F. J. H., 1966, Some Chemical Observations on Post-Glacial Lake Sediments, Philos. T. Roy. Soc. B, 256, 165-213.

Melles, M.; Brigham-Grette, J.; Minyuk, P. S.; Nowaczyk, N. R.; Wennrich, V.; DeConto, R. M.; Anderson, P. M.; Andreev, A. A.; Coletti, A.; Cook, T. L.; Haltia-Hovi, E.; Kukkonen, M.; Lozhkin, A. V.; Rosén, P.; Tarasov, P.; Vogel, H.; Wagner, B., 2012, 2.8 Million Years of Arctic Climate Change from Lake El'gygytgyn, NE Russia, Science, 337, 315-320.

Migdisov, A. A., 1960, On the Ratio of Titanium and Aluminum in Sedimentary Rocks, Geokhimia, 2, 149163 [In Russian].

Minyuk, P. S.; Borkhodoev, V. Ya., 2016, Geochemistry of Sediments from Lake Grand, Northeast Russia, Geochemistry International, 54 (9), 807-816.

Minyuk, P. S.; Borkhodoev, V. Y.; Wennrich, V., 2014, Inorganic Geochemistry Data from Lake El'gygytgyn Sediments: Marine Isotope Stages 6-11, Climate of the Past, 10, 467-485.

Minyuk, P. S.; Borkhodoev, V. Ya.; Goryachev, N. A., 2011, Geochemical Characteristics of Sediments from Lake El'gygytgyn, Chukotka Peninsula, as Indicators of Climatic Variations for the Past $350 \mathrm{ka}$, Doklady Earth Sciences, 436, Part 1, 94-97.

Minyuk, P. S.; Brigham-Grette, J.; Melles, M.; Borkhodoev, V. Ya.; Glushkova, O. Yu., 2007, Inorganic Geochemistry of El'gygytgyn Lake Sediments, Northeastern Russia, as an Indicator of Paleoclimatic Change for the Last 250 kyr, J. Paleolimnology, 37, 123-133.

Minyuk, P. S.; Lozhkin, A. V.; Anderson, P. M.; Solomatkina, T. B.; Pakhomov, A. Yu.; Borkhodoev, V. Ya., 2007, Multiproxy Studies of Sediments from Engtery Lake, North-East Russia, Vestnik NESC FEB RAS, 4, 2-13 [In Russian].

Minyuk, P. S.; Nowaczyk, N. R.; Glushkova, O. Yu.; Smirnov, V. N.; Brigham-Grette, J.; Melles, M.; Cherepanova, M. V.; Lozhkin, A. V.; Anderson, P.; Matrosova, T. V.; Hubberten, H.; Belaya, B. V.; Borkhodoev, V. Ya.; Forman, S. L.; Asikainen, C.; Layer, P.; Nolan, M.; Prokein, P.; Liston, C.; Nantzinger, R.; Sharpton, B.; Niessev, F., 2003, Paleoclimatic Data from El'gygytgyn Lake, the North-East of Russia (All-Round Studies), The 
Process of Post-Depositional Magnetization and Characteristic Changes of the Earth's Magnetic Field and Climate in the Past, Magadan, NEISR FEB RAS, 91-135 [In Russian].

Minyuk, P. S.; Subbotnikova, T. V.; Anderson, P. M.; Lozhkin, A. V., 2013, Rock Magnetic Properties of the Lake Pernatoe Sediments (Paramushir Island) as an Indicator of the Changes in Sedimentation Conditions, Izvestiya, Physics of the Solid Earth, 49 (1), 120-129.

Minyuk, P. S.; Subbotnikova, T. V.; Plyashkevich, A. A., 2011, Measurements of Thermal Magnetic Susceptibility of Hematite and Goethite, Izvestiya, Physics of the Solid Earth, 4 (9), 762-774.

Moreira, S.; Costa, P. J. M.; Andrade, C.; Lira, C. P.; Freitas, M. C.; Oliveira, M. A.; Reichart, G.-J., 2017, High Resolution Geochemical and Grain-Size Analysis of the AD 1755 Tsunami Deposit: Insights Into the Inland Extent and Inundation Phases, Marine Geology, 390, 94-105.

Munroe, J. S., 2012, Lacustrine Records of Post-Glacial Environmental Change from the Nulhegan Basin, Vermont, USA, Journal of Quaternary Science, 27 (6), P. 639-648.

Nesbitt, H. W.; Young, G. M., 1982, Early Proterozoic Climates and Plate Motions Inferred from Major Element Chemistry of Iutites, Nature, 299, 715-717.

Nesbitt, H. W.; Young, G. M., 1984, Prediction of Some Weathering Trends of Plutonic and Volcanic Rocks Based on Thermodynamic and Kinetic Considerations, Geochim. Cosmochim. Acta, 48, 1523-1534.

Nesbitt, H. W.; Young, G. M.; McLennan, S. M.; Keays, R. R., 1996, Effects of Chemical Weathering and Sorting on the Petrogenesis of Siliciclastic Sediments, with Implications for Provenance Studies, The Journal of Geology, 104, 525-542.

Peinerud, E. K., 2000, Interpretation of $\mathrm{Si}$ Concentrations in Lake Sediments: Three Case Studies, Environmental Geology, 40 (1-2), 64-72.

Rapuc, W.; Sabatier, P.; Arnaud, F.; Palumbo, A.; Develle, A.-L.; Reyss, J.-L.; Augustin, L.; Régnier, E.; Piccin, A.; Chapron, E.; Dumoulin, J.-P.; von Grafenstein, U., 2019, Holocene-Long Record of Flood Frequency in the Southern Alps (Lake Iseo, Italy) under Human and Climate Forcing, Global and Planetary Change, 175, 160-172.

Reynolds, R. L.; Rosenbaum, J. G.; Rapp, J.; Kerwin, M. W.; Bradbury, J. P.; Colman, S.; Adam, D., 2004, Record of Late Pleistocene Glaciation and Deglaciation in the Southern Cascade Range. I. Petrological Evidence from Lacustrine Sediment in Upper Klamath Lake, Southern Oregon, Journal of Paleolimnology, 31, 217-233.

Ronov, A. B.; Migdisov, A., 1965, The Main Features of the Geochemistry of Elements-Hydrolysates in the Process of Weathering and Sedimentation, Geokhimia, 2, 131-158 [In Russian].

Ruxton, B. P., 1968, Measures of Degree of Chemical Weathering of Rocks, J. Geol., 76, 518-527.
Sauerbrey, M. A.; Juschus, O.; Gebhardt, A. C.; Wennrich, V.; Nowaczyk, N. R.; Melles, M., 2013, Mass Movement Deposits in the 3.6 Ma Sediment Record of Lake El'gygytgyn, Far East Russian Arctic, Climate of the Past, 9, 1949-1967.

Schmidt, M.; Leipe, C.; Becker, F.; Goslar, T.; Hoelzmann, P.; Mingram, J.; Muller, S.; Tjallingii, R.; Wagner, M.; Tarasov, P. E., 2019, A Multi-Proxy Palaeolimnological Record of the Last 16/600 Years from Coastal Lake Kushu in Northern Japan, Palaeogeography, Palaeoclimatology, Palaeoecology, 514, 613-626.

Speranza, F. C.; Giralt, S.; Lupo, L. C.; Kulemeyer, J. J.; Pereira, E. de los A.; López, B. C., 2019, Paleoenvironmental Reconstruction of the Semi-Arid Chaco Region of Argentina Based on Multiproxy Lake Records Over the Last Six Hundred Years, Ibid., 524, 85-100.

Strakhovenko, V. D.; Solotchina, E. P.; Vosel', Y. S.; Solotchin, P. A., 2015, Geochemical Factors for Endogenic Mineral Formation in the Bottom Sediments of the Tazheran Lakes (Baikal Area), Russian Geology and Geophysics, 56 (10), 1437-1450.

Sun, W.; Liu, E.; Zhang, E.; Shen, J.,2019, Geochemistry of the Holocene Sediments of Lake Chenghai, SW China, and its Implications for Paleoenvironmental Reconstruction, Quaternary International, 523, 80-88.

Tanaka, K.; Akagawa, F.; Yamamoto, K.; Tani, Y.; Kawabe, I.; Kawai, T., 2007, Rare Earth Element Geochemistry of Lake Baikal Sediment: its Implication for Geochemical Response to Climate Change during the Last Glacial / Interglacial Transition, Quaternary Sci. Rev., 26, 1362-1368.

Von Eynatten, H.; Tolosana-Delgado, R.; Karius, V., 2012, Sediment Generation in Modern Glacial Setting: Grain-Size and Source-Rock Control on Sediment Composition, Sediment. Geol., 280, 80-92.

Webster, N. A. S.; Loan, M. J.; Madsen, I. C.; Knott, R. B.; Brodie, G. M.; Kimpton, J. A., 2012, An in Situ Synchrotron X-Ray Diffraction Investigation of Lepidocrocite and Ferrihydrite-Seeded $\mathrm{Al}(\mathrm{OH})_{3}$ Crystallisation from Supersaturated Sodium Aluminate Liquor, Journal of Crystal Growth, 340, 112-117.

Wei, W.; Algeo, T. J., 2019, Elemental Proxies for Paleosalinity Analysis of Ancient Shales and Mudrocks, Geochimica et Cosmochimica Acta, https://doi.org/ 10.1016/1j.gca.2019.06.034

Wright, H. E. Jr.; Mann, D. H.; Glaser, P. H., 1984, Piston Corers for Peat and Lake Sediments, Ecology, 65, 657-659.

Yudovich, Ya. E.; Ketris, M. P., 2011, Geochemical Indicators of Lithogenesis, Syktyvkar, Geoprint [In Russian].

Yudovich, Ya. E.; Ketris, M. P., 2014, Geochemistry of Manganese, Syktyvkar, IG Komi SC UD RAS [In Russian]. Zhong, W.; Pen, Z.; Xue, J.; Ouyang, J.; Tang, X.; Cao, J., 2012, Geochemistry of Sediments from Barkol Lake in the Westerly Influenced Northeast Xinjiang: Implications for Catchment Weathering Intensity during the Holocene, J. Asian Earth Sci., 50, 7-13. 